\title{
Oni, mais il faut parier Fidelidade e dúvida no Memorial de Aires
}

\author{
PEDRO MEIRA MONTEIRO
}

\begin{abstract}
“[...] Mais de quel côté pencherons-nous? La raison n'y peut rien déterminer. Il y a un chaos infini qui nous sépare. Il se joue un jeu, à l'extremité de cette distance infinie, où il arrivera croix ou pile: que gagerez-pous? Par raison vous ne pouvez faire ni l'un ni l'autre, par raison vous ne pouvez défendre nul des deux.

Ne blâmez donc pas de fausseté ceux qui ont pris un choix, car vous n'en savez rien! - 'Non, mais je les blâmerai d'avoir fait, non ce choix, mais un choix. Car encore que celui qui prend croix et l'autre soient en pareille faute, ils sont tous deux en faute. Le juste est de ne point parier.'

Oni, mais il faut parier. Cela n'est pas volontaire, vous êtes embarqué. [...]"
\end{abstract}

(Blaise Pascal. "Le discours de la machine”, v.1658)

\section{Um olhar distante}

$\mathrm{J}$ Á É QUASE um truísmo a afirmação do distanciamento do foco narrativo em certos romances de Machado de Assis. Distanciar-se, no caso, pouco tem a ver com o ideal de um ponto de vista neutro, ou de um olhar desfechado desde as alturas, onisciente e penetrante. Ao contrário, a penetração do olhar machadiano tem a ver com a dissimulação do ponto de vista: ocultas as razões daquele que escreve, os interesses que supostamente deram partida à escrita se borram e nos cremos diante de uma voz fundamentalmente desinteressada. Mas eis então que a armadilha nos captura, tornando-nos presa dos desejos ficcionais, é claro - do narrador, seja ele um rico e ocioso defunto, seja ainda o diplomata aposentado, cujo diário o escritor simula apenas reproduzir. ${ }^{1}$

De distanciamento se trata, sem dúvida, e o Memorial de Aires é pródigo nesses momentos em que a paixão mal contida (ou simuladamente mal contida) sublima-se no puro olhar ("puro gosto estético", diria o conselheiro Aires) do namorado que teme tocar o objeto, preferindo mirá-lo, ou simplesmente atravessá-lo com os olhos. Que os olhos se "enfiem" tão freqüentemente na prosa de Machado de Assis é de si eloqüente, sugerindo o poder da penetração idealizante, nunca realizada e por isso mesmo imperiosa em seu desejar. É corrente a identificação do olhar de Aires ao de um voyeur. ${ }^{2} \mathrm{O}$ que perturba na última narrativa machadiana tem, de fato, muito que ver com a impetuosidade com que 
o diplomata-escritor deseja o seu objeto, embora, por obrigação do ofício, deva constranger seus impulsos, mergulhando o ímpeto na água fria de uma prosa desinteressada, resultante de um olhar que parece sempre distanciar-se.

Não se diga, porém, que o procedimento é exclusivo do Memorial. Tal afastamento, que a um só tempo dissimula e aumenta o desejo da conquista, encontra-se também na prosa póstuma de Brás Cubas, galante e galhofeiro narrador que protege a si mesmo dos riscos do desejo, assim como encontra-se no casmurro Bento Santiago que, como Brás e o conselheiro Aires, escreve desde o ocaso. É no fim da vida, precisamente, que Bentinho toma da pena para exprimir o desejo que teima em provocá-lo, depois que o objeto querido foi violentamente rechaçado, ou simplesmente abandonado. Em graus e combinações diversas, o que temos, nos três famosos narradores, é o desejo irrealizado e certo remorso que ora se oculta, ora se revela, ora simplesmente insinua-se. Brás não amou Eugênia, para manter a classe; Bento abandonou Capitu e o filho, na vã tentativa de apagar o fantasma de Escobar; e o conselheiro Aires, levando ao paroxismo a afetação do desinteresse, delicia-se em duvidar da fidelidade de uma jovem e fresca viúva, como se quisera recuperar aquilo que havia deixado na Europa, enterrado para sempre. Curioso que as esposas de Bento e Aires sejam ambas sepultadas nessa Europa distante, uma na Suíça outra na Áustria, enquanto os desejos dos homens que lhes sobreviveram permanecem insepultos, como que forcejando por vir à tona, quando deles se esperaria que se reduzissem à quietude, finalmente consumidos pela vida e pelo tempo. Já vamos vendo que Brás não é o único “defunto autor" em questão, pois se trata, com freqüência em Machado de Assis, de entoar uma cantiga que, embora deliciosa, não recuperará jamais o que se deixou. ${ }^{3}$

Trata-se, como sugere a crítica, de um mundo em ruínas, narrado naquele tom lúgubre que bem pode evocar a imagem clássica da Melancolia a mirar, indiferente, o universo desfeito. Universo cuja recomposição, aliás, a narrativa sabe-se incapaz de levar a cabo. Mas nem por isso o Memorial de Aires é simples epitáfio. Conquanto a expectativa do entrecho romanesco não faça nenhum sentido, há em tal texto uma história, ou talvez várias histórias, como pode também aqui sugerir a crítica. ${ }^{4} \mathrm{~A}$ impressão, porém, é a de que a história nunca se revela completamente, como se a cada momento em que Aires descansa a pena houvesse algo ainda por contar, pondo a narrativa em constante suspensão.

Num jogo permanente com a materialidade da escrita - nas suas conversas com o papel, com a tinta, no jogo teatral do ato de escrever, em suma -, o narrador duvida da validade do que escreve, ameaçando o próprio texto com a iminência do desaparecimento: "Papel, amigo papel, não recolhas tudo o que escrever esta pena vadia [...] Quando sentires que insisto nessa nota, esquiva-te da minha mesa, e foge. A janela aberta te mostrará um pouco de telhado, entre a rua e o céu, e ali ou acolá acharás descanso". ${ }^{5}$

Ao utilizar a forma do diário, devemos supor que o narrador, conquanto ficcional, escreva de si para si. Mas, para além da subjetividade posta em 
cena, a voz da desconfiança nos envolve e envolve a todos, pondo em suspenso o próprio mundo. Pôr o mundo em suspenso é a forma máxima de testá-lo, de perscrutá-lo, olhando-o com a falsa passividade dos que, feita uma aposta, aguardam que o giro da vida se conclua, para confirmar o acerto ou desacerto de seu lance inicial.

O olhar distante é assim um olhar de afastamento porque, uma vez selada a aposta, não há mais nada a fazer senão observar, de longe. O olhar distante, entretanto, é também, e ao mesmo tempo, aquele que descansa em um ponto longínquo, como se buscasse o futuro, na esperança de que o mundo e seus movimentos apenas corroborem a miragem inicial que, sabemos, está na partida de toda aposta.

Ocorre que não há aqui roleta nem cartas, mas tão-somente os homens e seus deslocamentos. O olhar distante ganha então uma dimensão especial: o fictício Aires observa o presente, esperando que, perfeita a ação, confirme-se sua suspeita inicial. Enfim, o mundo dos homens é o campo de observação daquele que fez a aposta. A pena, entretanto, não pode suspender-se senão para retomar a narrativa, no dia seguinte, deitando suas notas ao papel esquivo. Desse jogo de suspensão (e suspeição) nasce o memorial, que nada mais é, no caso, que o registro diário da ação dos homens por aquele que fez uma aposta, duvidando de sua fidelidade. Tanto pior que, para o leitor do Memorial de Aires, Fausto não seja senão uma referência literária. No mundo do conselheiro, apostadores e não apostadores são todos apenas, ou demasiado, humanos.

\section{Uma aposta entre os mortos}

O Memorial de Aires inicia-se com uma aposta. De fato, não a aposta mefistofélica feita nas alturas, que Aires narra à sua irmã logo antes do almoço, após a visita que fizeram ao cemitério (MA, 10 de janeiro de 1888). Não há, nesse memorial, demônio algum a adentrar janelas, nem embate celeste que transforme a vida dos homens em um espetáculo a mirar-se desde cima. Há apenas uma singela aposta, selada depois que o conselheiro, não se sabe "por que inspiração maligna", duvida que a jovem viúva Fidélia, que ele vira no cemitério, não viesse a desmanchar os laços que ainda a uniam ao marido morto, contraindo novas núpcias. ${ }^{6}$

No bonde, de volta à casa, mana Rita relata a Aires a felicidade que a viúva Noronha (como é chamada Fidélia, com freqüência, no Memorial) experimentara em sua curta convivência com o esposo. É o momento em que uma reflexão do conselheiro inaugura a dúvida (com) que perseguirá Fidélia, dali em diante: "Não quer dizer que não venha a casar outra vez".

Já aí, no segundo dia do memorial, a curta reflexão fornece a clave que dará tom ao resto da narrativa: "não quer dizer que...".

Em suma, pode ser, mas pode também não ser que a viúva mantenha sua fidelidade ao morto. Uma vez lembrado que pode não ser, já a pureza da ação e dos gestos de Fidélia se mancharam, de forma tão mais irremediável quanto a 
reflexão parece desinteressada. Esse é o segredo da fala de um diplomata, capaz de encapsular o veneno na mais despretensiosa das frases, guardando-o entretanto, como a sinalizar que, a qualquer momento, ele pode derramar seu efeito letal. ${ }^{7}$ Lendo o Memorial de Aires, estamos sempre percorrendo um chão de suspeitas, das quais a bonomia do narrador parece proteger-nos, ao mesmo tempo que, paradoxalmente, as recorda. Trata-se de um veneno que se atenua na fala branda do conselheiro, mas cuja presença essa mesma fala atualiza, revelando-se tanto maldosa quanto ingênua, nunca de todo sinistra, mas tampouco capaz de inspirar confiança.

Na visita ao cemitério, em 10 de janeiro de 1888, Aires louva os túmulos velhos e enegrecidos, que dão "melhor impressão do ofício" que os jazigos novos e brilhantes. Para além da constatação do poder de corrupção do tempo, que é causa suficiente para a destruição dos corpos e das edificações humanas, há, nas reflexões do conselheiro, certo jogo sutil, senão mesmo certo prazer com a constatação da ausência absoluta de movimento: "A impressão que me dava o total do cemitério é a que me deram sempre outros; tudo ali estava parado. Os gestos das figuras, anjos e outras, eram diversos, mas imóveis" (MA, 10 de janeiro de 1888).

A prosa de Machado de Assis possui amiúde, sobretudo em sua última fase, um tom que bem se pode encontrar no Eclesiastes, onde a vida dos homens, suas obras e esperanças apenas confirmam a vanidade das glórias e vaidades que, como tudo o mais, o tempo consome. Há, em tal sabedoria ancestral, um misto de desencanto profundo e discreto encantamento pela vida, em seu caráter cíclico. Ocorre que, lido o Eclesiastes, o que um dia pode ter sido confiança nos homens e em suas possibilidades converte-se em certeza sobre o efêmero da obra humana. ${ }^{8}$ As conseqüências políticas de tal desencanto são importantíssimas, já que o olhar desde aí desfechado jamais deixará que nos convençam quaisquer gestos dos homens, sejam baixos, sejam sublimes. Afinal, diante do tempo, todo movimento é vão. Nasceria aí, sugere certa vertente da crítica, uma sorte de ceticismo radical diante de toda ideologia, convidando o leitor a desmontar, por meio dos retratos que a narrativa oferece, a inteireza moral e política dos indivíduos, buscando aos seus gestos, públicos ou privados, a farsa escondida. ${ }^{9}$

Aqui, entretanto, apenas me interessa perceber como aquele retrato estático dos cemitérios, ao evocar a eternidade e o poder estuante do tempo, faz pensar na vanidade de todos nós, que, um dia, afinal, também havemos de ingressar na academia dos estudiosos da "geologia dos campos santos", segundo a notação jocosa do Bento de Dom Casmurro (Assis, 1992, v.1, p.810). Não à toa, adentramos o Memorial de Aires pelo cemitério.

Interessa ainda notar que, assim como no Eclesiastes o poder do tempo precisa da tenuidade do humano para confirmar-se, também no retrato do cemitério, no Memorial, a impressão do mundo estático parece reclamar algum movimento, como se apenas do contraste pudesse nascer o quadro em que Machado de Assis, pelo olhar do conselheiro Aires, pretende situar-nos. De fato, 
em seguida à constatação de que "tudo ali estava parado", lemos: "Só alguns pássaros davam sinal de vida, buscando-se entre si e pousando nas ramagens, pipilando ou gorjeando. Os arbustos viviam calados, na verdura e nas flores".

A vida se insinua, ligeira, no cenário quase todo parado. Tal "impressão" do cemitério, tem-na o conselheiro logo antes de divisar a viúva e flagrar-lhe os gestos de respeito e saudades diante do túmulo do marido. É legítimo perguntar: que fazem os passarinhos aí, a contrastar, com seu pipilar inquieto, a serenidade de pedra do local? Entre os arbustos, que se calam em sua verdura e em suas flores, e as estátuas, que fixam o movimento em gestos eternos, corre um fio de vida, ou de som, rompendo a intemporalidade. É o momento em que Aires traz, ao centro da cena, Fidélia. Então o olhar se desloca (ou seja, o narrador desloca nossa atenção) para acompanhar os movimentos da viúva.

Após saber da irmã quem era a encantadora ("moça", "bonita", "gentilíssima”) senhora, Aires estaciona no portão do cemitério a mirá-la. O que vê, e como vê, reclama uma citação completa:

Nesse momento, a viúva descruzava as mãos, e fazia gesto de ir embora. Primeiramente espraiou os olhos, como a ver se estava só. Talvez quisesse beijar a sepultura, o próprio nome do marido, mas havia gente perto, sem contar dous coveiros que levavam um regador e uma enxada, e iam falando de um enterro daquela manhã. Falavam alto, e um escarnecia do outro, em voz grossa: "Eras capaz de levar um daqueles ao morro? Só se fossem quatro como tu". Tratavam de caixão pesado, naturalmente, mas eu voltei depressa a atenção para a viúva, que se afastava e caminhava lentamente, sem mais olhar para trás. Encoberto por um mausoléu, não a pude ver mais nem melhor que a princípio. Ela foi descendo até o portão, onde passava um bonde em que entrou e partiu. Nós descemos depois e viemos no outro. (MA, 10 de janeiro de 1888)

Ali onde esperávamos devoção ao morto, Fidélia lança um olhar à volta, "como a ver se estava só". Por que o olhar lançado? Estaria aí a anunciar-se, como quer John Gledson (1985), a primeira de uma série de traições? Ou estaríamos apenas testemunhando o império irresistível da opinião ${ }^{10}$ São perguntas para as quais não há, nem deve haver, resposta: tudo se mantém em suspensão, ou na suspeição.

De qualquer forma, a constelação que aqui se arma deixa ver passar, no comentário sacrílego do coveiro, o peso do morto. ${ }^{11}$ Os gestos da viúva, por sua vez, fossem eles tão devotos quanto se espera, poderiam bem imortalizar-se num quadro edificante, confundindo-se porventura às estátuas, todos "diversos, mas imóveis".

Adivinhamos, entretanto, o nervosismo do gesto, porque já no meio do parágrafo vemo-nos mergulhados na dúvida em que nos lançou o conselheiro: "Talvez quisesse beijar a sepultura, o próprio nome do marido". O advérbio ("talvez") é o índice de indeterminação que capta a ação em seus inícios, mas não deixa que ela se perfaça diante dos olhos do leitor. Não sabemos se a viúva de fato deixaria o ósculo sagrado na sepultura, ou se simplesmente abandonou 
o túmulo para livrar-se do peso daquele morto. Se a intenção da personagem é impenetrável, podemos contudo supor que a intenção do narrador não é neutra; ou antes, que ela se esconde atrás da neutralidade aparente do observador que, fiel apenas à sua narrativa, não pode (ou não quer) afirmar nem que sim, nem que não. "Talvez" é o máximo a que chegamos, levados pelas mãos de Aires.

Tomados pela dúvida, somos partícipes de uma cena em que os movimentos se congelaram, como se um fio de suspeita houvesse suspendido os gestos no instante em que eles ainda não são capazes de revelar as intenções que movem o indivíduo. Ou ainda, podemos supor que a arte de Machado de Assis já ia anunciando a complexidade dos caminhos que levam a compreender as motivações dos seres humanos, impenetráveis, invisíveis até para o sujeito que age e pensa. Porém, abandonemos por ora a tentação de supor que Machado mergulhasse, com sua escrita, nos abismos da conformação da individualidade. Sua clínica é um pouco outra, se assim se pode dizer. ${ }^{12}$

A análise em tela deixa ver a conformação moral da personagem, fazendo assomar, nos titubeios da viúva, logo no início, a dúvida sobre a fidelidade. A dinâmica é complexa e sutil, porque os gestos parecem congelar-se, mas é nesse instante que sentimos algo a vibrar, na indecisão do sujeito. Aí, precisamente, vemos assomar a agulha da suspeita, que vai tecendo devagar a narrativa, sem que no mais das vezes possamos perceber que Aires nos está guiando, semeando dúvidas à medida que cerca a adorável Fidélia.

Ainda no plano dos movimentos, já será lícito supor que aqueles passarinhos, "buscando-se entre si e pousando nas ramagens", representem, quase metonimicamente, o movimento inquieto dos sentimentos que, devemos suspeitar, se encontram e desencontram na alma da viúva, a qual penetraremos com os olhos extremosos do conselheiro Aires, que por sua vez afeta desinteresse ali exatamente onde o desejo floresce, isto é, no cemitério em que se engendra a aposta.

\section{A dúvida posta em cena}

A paixão de Machado de Assis pela música já rendeu diversas reflexões críticas. ${ }^{13}$ Amiúde em seus textos, encontramos referências à cena musical fluminense, incluindo, e especialmente, a ópera. No caso do Memorial de Aires, além da freqüência com que Tristão e Fidélia vão ao piano, há, nos nomes dos filhos postiços do casal Aguiar, a evidente referência operística, apontando para Wagner e Beethoven, respectivamente.

Antes, porém, de explorar aquilo a que poderíamos porventura imaginar como um intertexto operístico no Memorial de Aires, vale a pena supor que Machado de Assis estivesse especialmente tomado pela idéia da ópera, quando escrevia seu derradeiro livro. Há cenas inteiras, no jornal de Aires, em que se nota certa teatralidade musical. ${ }^{14}$ Ao menos uma vez, a musicalidade da cena se explicita de tal forma, que podemos acreditar-nos diante de um dueto, ou mais precisamente de um trio, como numa boa composição operística. É uma pas- 
sagem longa, que vale a pena reler. Data de 11 de novembro de 1888, dia em que o conselheiro vai à casa dos Aguiares ver se Fidélia terminara a marinha que andara pintando. Estão Tristão e dona Carmo a assistir à arte da jovem viúva, quando o velho diplomata se junta a eles. Após um protocolar elogio ao quadro, Aires ouve de Tristão expressões de louvor à pintura. São palavras

cálidas, sinceras decerto, que a viúva apreciou consigo naturalmente; não as contestou, também não sorriu como sucede quando a gente aprova interiormente uma coisa que lhe vai bem com a alma. Ouviu pintando, recuando ou chegando, e deitando os olhos para longe. Quando os encaminhou para ele (já então sentado) não esperou que Tristão afastasse os seus; encontrou-os e deixou-os ficar onde estavam, indo continuar a marinha com tanta atenção que era como se nós outros não falássemos de nada, e nós falávamos de muita coisa, ele acaso menos, para ver melhor a pintura.

Aquele silêncio de Fidélia, em contraste com a palestra de pouco antes, pareceume indicar que ela considerava a obra em atraso. Também podia ser que o amor da arte a retivesse agora mais que a princípio, e a convidasse a pintar exclusivamente. A causa secreta de um ato escapa muita vez a olhos agudos, e muito mais aos meus que perderam com a idade a natural agudeza; mas creio que seria uma daquelas, e não há razão para descrer que fossem ambas sucessivamente.

Quem parecia contente de tudo, palavras e silêncios, era a dona da casa. Posto me desse a principal atenção, não o fazia em maneira que esquecesse a tela e os filhos. Mirava a tela e falava aos filhos com a ternura velha que já estou cansado de notar, e talvez a ternura fosse agora maior que de outras vezes; pelo menos, trazia certo alvoroço como de alma que soletra uma felicidade nova ou inesperada; não digo tudo para me não arriscar a engano.

A verdade é que eu, que pensara em sair, fui ficando, ficando, até que a viúva Noronha suspendeu o trabalho; tinha passado quase uma hora. Confessou que estava cansada, e cuidou de recolher os pincéis e cobrir a pintura, ajudada nisso pelo moço Tristão, que o fazia com a mesma graça que ela, e um desejo de bem servir, que é a alma da polidez. Eu, além de velho, não podia deixar a boa Carmo, que só os ajudou com os olhos, e ajudou-os bem; iam de um para outro, não só alegres, mais ainda interrogativos. Eles acabaram tudo e vieram sentar-se diante de nós, um cheio de riso, outra não cheia, mas tocada apenas do seu, que era igualmente agradecido e bom.

A minha presença era já longa, e apesar das relações que há entre nós, começaria a parecer indiscreta. Era tempo de sair; quis sair e ficar a um tempo, coisa impossível; vivi assim alguns instantes de impulsos contrários. Tristão podia resolver esta minha luta interior cantando alguma coisa que me obrigasse a ouvi-lo, mas estava então ocupado em dizer finezas à artista, à viúva, à irmã, a todas aquelas três pessoas consubstanciadas na mesma dama encantadora. Fidélia sorria com recato e atenção, e respondia também. Despedi-me, e achei (se não foi engano) que D. Carmo estimou a minha saída para se dar inteiramente aos dois filhos. Certo é, porém, que os três me falaram com apreço e cortesia. Vim por aí fora pensando neles. (MA, 11 de novembro de 1888)

O deslocamento dos personagens, os olhares, os sentimentos dos dois Tristão e Fidélia - consubstanciados em um só, seus gestos assistidos de perto 
pela velha Carmo, tudo parece compor uma cena que seria um belo trio, não fora a participação de uma quarta voz, que é justamente o foco da narração e, a essa altura já se pode concluir, da suspeição.

Primeiro, há esses olhos que Tristão deita à viúva e a sua arte, e que a mesma viúva recebe com demora: "encontrou-os e deixou-os ficar onde estavam". Enquanto isso, Aires e Carmo fazem o fundo da cena, fingindo conversar, enquanto a atenção toda do leitor-espectador se dirige ao canto principal, que é feito sobretudo desse olhar da viúva, oscilando entre a pintura e o mar: "era como se nós outros não falássemos de nada, e nós falávamos de muita coisa, ele [Tristão] acaso menos, para ver melhor a pintura".

Ainda que a atenção se volte toda para os olhos que se cruzam, D. Carmo se faz também parte da cena, e pode-se supor que aqui ouvimos umas notas de aprovação e alegria pelo enlace que vemos aos poucos selar-se: "trazia certo alvoroço como de alma que soletra uma felicidade nova ou inesperada". É uma bela forma de descrever o canto que exprime o júbilo da velha senhora, toda empenhada em acompanhar o idílio que se anuncia: "só os ajudou com os olhos, e ajudou-os bem; iam de um para outro, não só alegres, mais ainda interrogativos".

Terminada essa parte da cena, recolhidos os pincéis, os jovens sentam-se com os velhos, "um cheio de riso, outra não cheia, mas tocada apenas do seu, que era igualmente agradecido e bom". O idílio já vai longe, porém, e Aires sente que é hora de partir. O cenário é acolhedor ("quis sair e ficar a um tempo"), mas é preciso sair de cena, deixando que o canto se dirija ao destino correto: "Tristão podia resolver esta minha luta interior cantando alguma coisa que me obrigasse a ouvi-lo, mas estava então ocupado em dizer finezas à artista, à viúva, à irmã, a todas aquelas três pessoas consubstanciadas na mesma dama encantadora".

Não é a Aires que se deve dirigir o canto de Tristão, nem a Carmo, que apenas assiste a tudo embevecida. É àquela coincidência de mulheres, todas "consubstanciadas na mesma dama encantadora", artista-viúva-irmã, que se dirige a voz do moço. E lá ficam os três, Tristão, Fidélia e Carmo, a dar-se inteiramente uns aos outros, enquanto se retira Aires, "por aí fora pensando neles".

Finda a cena, somos levados a indagar o que terá ficado na mente desse espectador privilegiado que, assistindo a tudo, esteve no palco junto a seus próprios personagens. Aires é, nesse sentido, ele mesmo um personagem especial, a um só tempo analista e testemunha, agente supostamente desinteressado que deixa entretanto pingar sua "gota de fel do costume", como dirá em outra ocasião (MA, 5 de dezembro de 1888).

A dança dos olhares, Fidélia a afastar os olhos da tela e pousá-los nos olhos de Tristão, o jogo de silêncio e som, tudo é minuciosamente conduzido pelo narrador. $\mathrm{O}$ silêncio de Fidélia, justamente porque oculta qualquer mensagem, dá a Aires duas idéias, e podemos supor que nenhuma delas seja verdadeira. Se- 
gundo o conselheiro, a razão do silêncio que reina enquanto ela pinta, no início da cena, poderia estar no simples atraso da obra, que a obrigaria à operosidade com que a vemos (pelos olhos de Aires, sempre) entregar-se à pintura, ou talvez estivesse simplesmente no "amor à arte", que se revelaria especialmente agora, à medida que se concluía a marinha. Entretanto, pelas mãos (olhos e ouvidos) do narrador, somos confrontados a uma dúvida fatal: que arte opera Fidélia, que obra quer finalmente consumar?

Aires chama a atenção sobre o "silêncio" de Fidélia num momento em que nós leitores já flagramos os olhos da jovem viúva a se deixarem tocar pelo olhar de Tristão, logo antes que retornassem à tela e que mergulhassem novamente em sua arte silenciosa. O que tece Fidélia com os olhos, nesse momento? O que pensa o conselheiro, o que ele próprio tece no espaço vazio, depois que assistiu à cena (uma cena, nunca é demais insistir, que ele mesmo compõe) e saiu "por aí fora"?

\section{Poderosa miopia}

Evocadas as duas possíveis razões do silêncio de Fidélia (o atraso da obra ou o amor à arte), e ainda que ingenuamente as considerássemos suficientes para compreender os movimentos que se dão naquela cena, resta a dúvida profunda que, como sempre, instaura-se no cerne da narração: "A causa secreta de um ato escapa muita vez a olhos agudos, e muito mais aos meus que perderam com a idade a natural agudeza; mas creio que seria uma daquelas, e não há razão para descrer que fossem ambas sucessivamente".

Novamente assoma a dúvida, e com ela a possibilidade de que explicações diversas operem juntas, igualmente críveis. É claro que, simulando a miopia, Aires sugere que o embaçado do que vemos é falha sua, como observador: pode ser uma coisa, pode ser outra. Mas, ao chamar a atenção sobre a dúvida e sobre a agudeza supostamente perdida, ele nos convida a fazer o movimento que ele próprio, como bom diplomata, e como observador de fato agudo, poupou-se de fazer: reencontrar o foco justo e mergulhar fundo, a essa altura já completamente convencidos de que a viúva trama sua própria felicidade e que, ao tramá-la, termina por calcular cada gesto, guiando o som e o sentido de modo a tornar seu idílio aceitável, pouco a pouco traçando o caminho que a separa do segundo casamento.

Creio que aqui estejamos diante daquele mecanismo que tanto e justamente tem despertado a atenção da crítica, sugerindo o narrador não confiável que Machado de Assis trabalhou com maestria. Aires, pouco mais ou menos como o Bento de Dom Casmurro, tece sua própria rede de suspeitas, que enreda a todos, embora pareça poupar o narrador. Verdade que Machado não deixa a pena de seu conselheiro guiar-se pelo mesmo ciúme doentio que guiara Bentinho, mas, ainda assim, a escrita de Aires é uma geradora perpétua de suspeitas, tão mais poderosas quanto mais nos esquecemos dos interesses nem sempre virtuosos - sempre inconfessos, em todo caso - do narrador. 
Interessante que esse narrador fictício se deixe, em outro momento de seu diário, encantar-se pelo poder da fotografia, que então se desenvolvia a passos largos. Anunciado por fim o casamento de Tristão e Fidélia, Aires, já bem mais à frente no memorial, delicia-se com a idéia de penetrar a intimidade do casal:

Eu gosto de ver impressas as notícias particulares, é bom uso, faz da vida de cada um ocupação de todos. Já as tenho visto assim, e não só impressas, mas até gravadas. Tempo há de vir em que a fotografia entrará no quarto dos moribundos para lhes fixar os últimos instantes; e se ocorrer maior intimidade entrará também. (MA, 22 de fevereiro de 1889)

Parece que a miopia encontra aí, no delírio da vigília absoluta, sua compensação. Para além do aspecto algo premonitório dessa passagem, a sugerir que a atenção ao corpo e à privacidade poderia estar no fundamento de todo poder, devemos notar que o narrador se refere à possibilidade de penetrar os sentidos mais íntimos dos gestos e das ações sociais. Aqui o aspecto visual da experiência de observação de Aires pode sugerir aquilo justamente que a fotografia faz, isto é, fixar um quadro segundo o jogo complexo dos interesses que guiam o fotógrafo, e que o levam, justamente, a trabalhar com planos, foco, iluminação, perspectiva, movimento, de tal modo que, ao fim, a percepção do espectador se torna inseparável da orientação daquele que porta a câmara. Há aí um poder inegável, de que dispõe o proprietário do instrumento, seja ele o dono da câmara, seja o dono da pena.

Outra trama que se arma no Memorial de Aires diz respeito à autoridade - e ao poder - do escritor, que se esboroa à medida que a própria representaçãa se converte num tema, e a escrita se transforma em constante encenação. ${ }^{15} \mathrm{O}$ Memorial é, de certa forma, a posta em cena da escrita, como aliás o foram as Memórias póstumas de Brás Cubas, onde também está em evidência um narrador (como persona social e como escritor fingido) cujo poder se esvai, e que se refugia na sua escritura, tendo-a como derradeiro asilo para seus mandos e desmandos. Essa mesma escrita, poderíamos dizer com mais simplicidade, dá asilo aos desejos deste narrador meio morto, ou "aprendiz de morto", que é, na notação de José Paulo Paes, o conselheiro Aires.

Voltemos, porém, à influência da ópera, que aliás, à altura da publicação do Memorial de Aires, em 1908, já entrava em franca decadência. Vejamos como a rede da suspeita machadiana nasce, especialmente, do derradeiro poder da escrita de pôr em dúvida, subvertendo-a, a representação que associa a pureza do coração à transparência das ações. Houve um tempo, afinal, em que a encenação pôde ser a salvaguarda de valores tão altos como a fidelidade. Nada mais contrário ao mundo que encena Machado de Assis.

\section{Uma outra ópera}

Já se sugeriu com detalhes o quanto o entrecho de Tristão e Isolda poderia ajudar a compreender os deslocamentos amorosos de Tristão e Fidélia, no Memorial de Aires. ${ }^{16}$ Já a presença do entrecho do Fidelio, de Beethoven, parece 


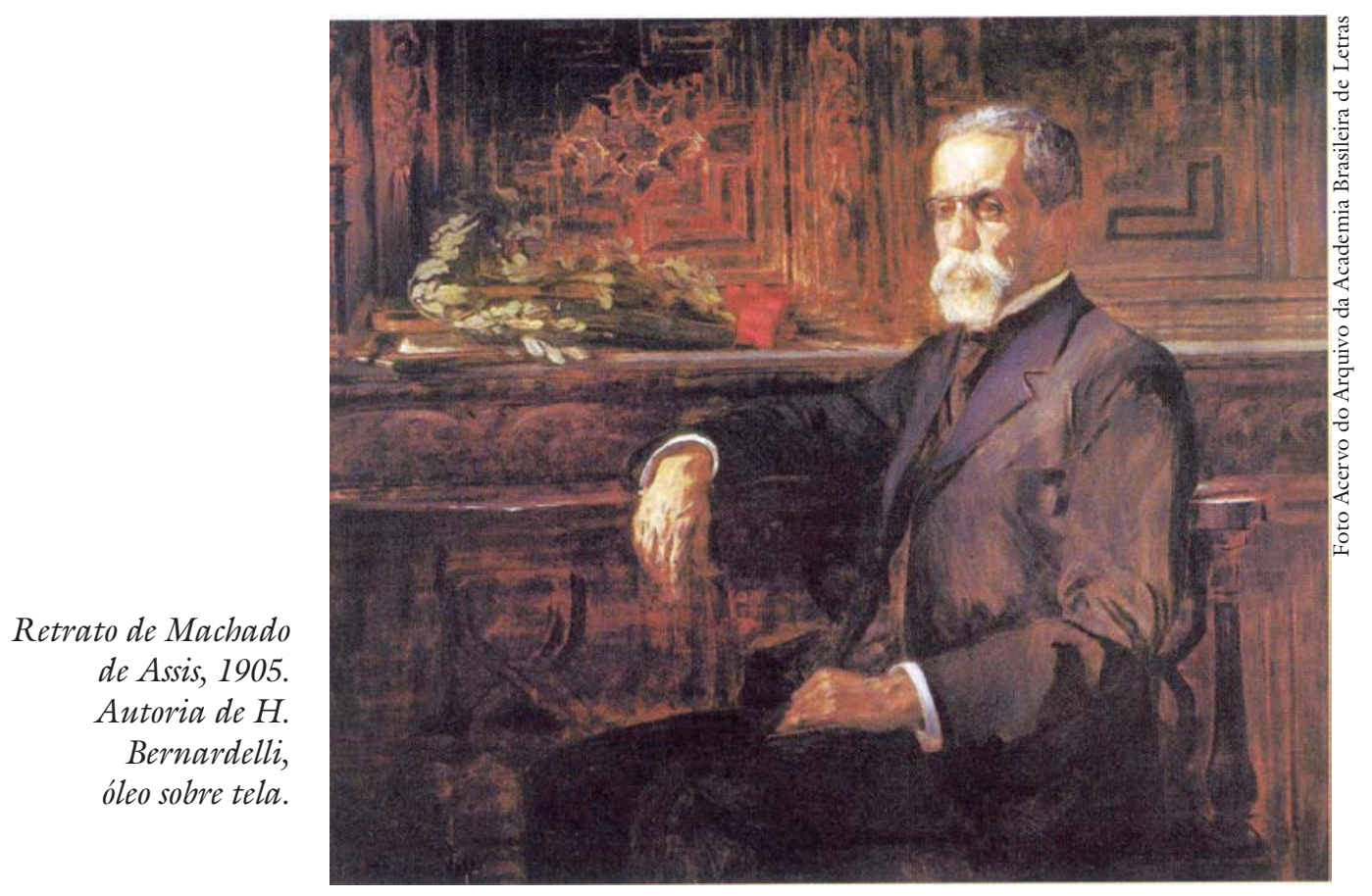

ser tema pouco menos trabalhado pela crítica machadiana, embora não seja menos importante, já que permite compreender, por contraste, onde no romance se instaura a dúvida e como, no plano das ações, compromete-se a vigência da fidelidade. ${ }^{17}$

Vale a pena, portanto, explorar algo que, como procurarei sugerir, terá ocupado a mente de Machado de Assis enquanto escrevia seu livro. Penso aqui no jogo entre a máscara e a essência que, coincidentes na história original do Fidelio, revelam-se fundamentalmente divergentes no texto machadiano. Somente na ópera se elabora uma fidelidade resistente a todas as provações, não no diário de Aires. ${ }^{18}$

O entrecho do Fidelio nos transporta a uma prisão espanhola, onde encontramos cativo o valoroso Florestan, condenado por um perverso governador, Don Pizarro. A esposa de Florestan, Leonora, disfarça-se para adentrar a prisão e aproximar-se do marido. A máscara que utiliza - masculina - é a de Fidelio. Ocorre, contudo, que a filha do carcereiro Rocco, a bela Marcelina, apaixonase pelo herói (que é de fato Leonora sob as vestes de Fidelio). Para complicar o entrecho e sustentar um dos triângulos amorosos que movimentam a trama, Jaquino, porteiro e auxiliar de Rocco, está perdidamente apaixonado por Marcelina, e elegerá portanto Fidelio como seu opositor e rival.

As peripécias todas levam a um desfecho, evidentemente apoteótico, em que se conjugam e se enlaçam as almas, quando Fidelio, podendo finalmente tornar-se Leonora, rompe as cadeias que prendiam o marido - momento em que, reinstaurada a justiça, o vilão Pizarro é banido. É sobre essa trama que glosa porventura Machado de Assis, numa escuta delicada, mas ao mesmo tempo profundamente perversora do sentido original. 
Há sem dúvida inquietantes questões de gênero a rondar a história cuja heroína, para confirmar seus valores (em especial a fidelidade conjugal), deve atuar como um homem, despertando paixões cruzadas, como a da filha do carcereiro que administra a prisão onde se encontra seu marido. Interessa-me aqui, contudo, perceber como a proximidade com o Outro, que é o desvio da relação conjugal, reativa em Leonora o sentimento da fidelidade. Em outros termos, reagindo, ou mostrando-se indiferente à paixão de Marcelina, Leonora confirma o poder da máscara que porta: Fidelio.

$\mathrm{Na}$ cena 3 do primeiro ato, vemos Marcelina encantada por Leonora, crente de que ele (Fidelio) a ama. Neste momento, precisamente, Leonora se vê diante da ameaça de um rompimento - a perda da esperança e da fidelidade, - quando percebe que Marcelina a ama, ainda que o amor desta se dirija à máscara, ao Fidelio que a um só tempo oculta e revela os motivos de Leonora. Diante da aprovação do pai de Marcelina, contudo, é Jaquino que se desespera, por ver-se preterido. Eis o que nos traz o famoso quarteto:

\section{MARZELLINE}

(Mit ist so wunderbar, Es engt das Herz mir ein;

Er liebt mich, es ist klar,

Ich werde glücklich sein.)

\section{LEONORE}

(Wie groß ist die Gefahr, Wie schwach der Hoffnung Schein!

Sie liebt mich, es ist klar,

O namenlose Pein.)

\section{ROCCO}

(Sie liebt ihn, es ist klar.

Ja, Mädchen, er wird dein.

Ein gutes, junges Paar,

Sie werden glïcklich sein.)

\section{JAQUINO}

(Mir sträubt sich schon das Haar,

Der Vater willigt ein.

Mir wird so wunderbar,

Mir fällt kein Mittel ein.)

\section{MARCELINA}

(Que estranha sensação

Me comprime o coração;

Ele me ama, é claro,

Eu serei feliz.)

\section{LEONORA}

(Quão grande é o perigo, Quão débil o brilho da esperança!

Ela me ama, é claro,

Ó inominável tormento.)

\section{ROCCO}

(Ela o ama, é claro.

Sim, menina, ele será teu.

Um bonito jovem casal,

Serão felizes.)

\section{JAQUINO}

(Crispam-se-me os cabelos, O pai consente.

Sinto algo tão estranho, Não vejo remédio algum.)

Claro, há que ouvir a leveza do canto inicial de Marcelina, cada sílaba marcada pelo pizzicato nas cordas, revelando contudo a discreta vibração, que deixa 
vazar a emoção interior da descoberta daquela "estranha" sensação que a toma. Tão mais envolvente se torna o fraseado quanto podemos ouvir a clarineta ao fundo, límpida, repetindo quase perfeitamente a frase melódica. Aqui, a cena do cemitério, no Memorial de Aires, merece ser lembrada: quase não há crispação, só a beatitude do canto que, no entanto, se bem entoado, revelará esse tremor discreto da alma, essa paixão que adeja e ameaça tomar conta do corpo, mas que nunca passará de ligeira vibração, como aqueles passarinhos que quebravam a monotonia do cenário descrito pelo conselheiro. Uma alma que deseja, enfim. Ou um desejo que se revela aos poucos, que toma e preme o coração.

Aí, entretanto, vemos o canto de temor de Leonora enredar-se ao de Marcelina, em dúvida e pasmo, sempre acompanhado do agudo das flautas, expondo, ao lado da certeza de que ela $a(0)$ ama, o receio de que o brilho da esperança (do reencontro, da fidelidade a manter-se) seja demasiado fraco, e se apague. Pode ser simplesmente indescritível (e o Memorial, diga-se de passagem, flerta com a música também nisto, que é a lida constante com o indescritível das sensações) - será simplesmente indescritível o entrelaçamento dos cantos das duas sopranos que, num crescendo ao qual em breve juntar-se-ão o baixo (Rocco) e o tenor (Jaquino), formam uma espécie de hélice aérea, agora dupla, depois tripla e logo mais quádrupla: duas, três e quatro linhas melódicas que se enlaçam e ameaçam tocar-se, mas que graciosamente se afastam umas das outras, numa complexidade sonora que, se não traz ainda o êxtase do reencontro, trata ao menos de anunciá-lo, ou prenunciá-lo, abrindo-nos às vistas o horizonte de bem-aventurança em que deveremos situar-nos, ao fim de tudo.

É em todo caso fundamental que o triângulo (Jaquino, Marcelina e Leonora/Fidelio), acompanhado de perto pelo pai de Marcelina, desenvolva o sublime canto do enlace, deixando, entretanto, que a dúvida ameace o brilho do laço amoroso: Wie groß ist die Gefahr, Wie schwach der Hoffnung Schein! Mas justamente diante do perigo do rompimento confirmamos a existência do laço, em seu brilho fugaz e poderoso. O temor de Leonora prova que a união original (a fidelidade) mantém-se, embora a ameaça mergulhe a disfarçada heroína em uma dor inominável (namenlose Pein).

O inominável, o inefável, que numa tradição romântica confunde-se ao sublime, está todo, como não poderia deixar de ser, em Beethoven. Se é possível falar em uma poética musical, será então razoável sugerir que a sua música busque, amiúde, a inefabilidade, ou este mais além que será figurado no pleno encontro, na alegria gloriosa da comunhão do gênero humano. Se a prisão do Fidelio já foi comparada à Bastilha, que caíra apenas algumas décadas antes da composição, vale também lembrar que tal busca da harmonia final do gênero humano é um traço schilleriano que, por seu turno, pode lembrar-nos de como, em sua única ópera, Beethoven anuncia o que viria a ser o coral no último movimento da Nona sinfonia, quando os homens, rompidas as cercas que os separam, comungam na alegria inextinguível do canto coletivo. ${ }^{19}$ 
Atendo-nos ao Fidelio, resta verificar como, já ao final, na cena 15 do segundo ato, o reencontro dos amados é também um momento de indizível e gloriosa alegria. Haverá, é verdade, o coro posterior dos prisioneiros libertados, mas deixemos de lado, aqui, a força e a significação do canto coletivo, para ouvir apenas o canto de Leonora e Florestan, notando, desde já, a quantidade de sensações inexprimíveis, e os correlatos adjetivos a designar o inominável:

\section{LEONORE}

O namenlose Freude!

Mein Mann an meiner Brust!

FLORESTAN

O namenlose Freude!

An Leonorens Brust!

BEIDE

Nach unnennbarem Leide So ubergroBe Lust!

LEONORE

Du wieder nun in meinen Armen!

FLORESTAN

O Gott,

wie groB ist dein Erbarmen!

BEIDE

O Dank Dir, Gott, fur diese Lust!

\section{LEONORE}

Mein Mann, mein Mann an meiner Brust!

\section{LEONORA}

Ó alegria indizível!

Meu esposo em meus braços!

\section{FLORESTAN}

Oh, alegria indizível!

Nos braços de Leonora!

\section{AMBOS}

Depois de inenarráveis tormentos

Que alegria enfim!

\section{LEONORA}

Uma vez mais te abraço!

\section{FLORESTAN}

Ó Deus, como é grande Tua misericórdia!

\section{AMBOS}

Te agradecemos, Senhor, por esta alegria!

\section{LEONORA}

Meu marido, meu marido em meus braços! 
FLORESTAN

Mein Weib,

mein Weib an meiner Brust!

Du bist's!

LEONORE

Ich bin's!

FLORESTAN

O himmlisches Entzucken!

LEONORE

Du bist's!

FLORESTAN

Ich bin's!

LEONORE

O himmlisches Entzucken!

FLORESTAN

O Leonore!

LEONORE

Florestan!

BEIDE

O namenlose Freude!

Nach unnennbarem Leiden So ubergroBe Lust!

\section{FLORESTAN}

Minha esposa,

minha esposa em meus braços! És tu!

\section{LEONORA}

Sim, eu!

\section{FLORESTAN}

Ó delícia celeste!

\section{LEONORA}

És tu!

\section{FLORESTAN}

Sim, cá estou!

LEONORE

Ó delícia celeste!

\section{FLORESTAN}

Ó Leonora!

\section{LEONORA}

Florestan!

\section{AMBOS}

Ó inominável alegria! Após incontáveis tormentos Que infinita alegria! 


\section{FLORESTAN}

Mein Weib, mein Weib an meiner Brust!

\section{BEIDE}

Du wieder mein, an meiner Brust! O Dank Dir, Gott, fur diese Lust!

\section{FLORESTAN}

Minha esposa, minha esposa em meus braços!

\author{
AMBOS \\ Uma vez mais, em meus braços! \\ Te agradecemos, Senhor, \\ por esta alegria!
}

Não fora evidente o corte romântico da cena, poderíamos lembrar outra sorte de comunhão. Refiro-me ao divino gozo que parece roubar os amantes ao mundo do século, com o rapto celeste que entrega a alma pecadora ao Esposo, ou ao corpo místico em que se consubstanciam a Igreja e o Cristo, dando forma à poesia religiosa de um San Juan de la Cruz ou, no quadrante americano, à poesia de Sór Juana Inés de la Cruz.

Aqui, porém, outro é o movimento, outro o rapto. Somos tomados, a bem da verdade, pela vertigem do encontro dos seres humanos, e o canto, para emprestar livremente uma expressão ao Dom Casmurro, faz-se "aos saltinhos". Logo de início, o crescendo vertiginoso das cordas abre a cortina à cena principal, onde sobressai a força do canto de Leonora, em sua (verbalmente) inexprimível alegria. Tudo alegria, tudo canto, até o extremo em que não há mais o que fazer ou dizer, senão simplesmente repetir o nome do amado, num êxtase em que se cancelam a história, os tormentos, e só restam os dois sujeitos, num só: Florestan, Leonora.

A delícia sonora, celeste, daria muito o que escrever. Pensando, entretanto, na escuta e na atenção de Machado de Assis, vale notar que o laço de amor e fidelidade, no Fidelio, sustenta-se não apenas porque Florestan é, ou foi um dia, o objeto amado. Florestan é também o sujeito de uma alucinação que mantém viva a chama, a qual não deve apagar-se jamais. Trata-se de uma chama inextinguível exatamente porque o sujeito/objeto da paixão está vivo, ainda que no limite da morte. A sobrevida de Florestan - e da paixão que une os esposos - é sustentada pela permanência de um mundo espectral, em que, mesmo ausente, o amante sabe que o outro pode ser buscado, e então vive da vertigem de um encontro ora possível ora impossível: como a última chama, bruxuleante. Sem adentrar minúcias psicanalíticas, vale lembrar, muito simplesmente, que lidamos com um objeto ausente, e que a paixão se desdobra e descobre no intervalo que me separa do Outro, sobre cujo lugar eu sei pouco, ou nada sei.

O sentimento amargurante do desencontro, da busca ininterrupta do $\mathrm{Ou}^{-}$ tro (que pode ser apenas uma alucinação, e o é quase sempre), mergulha o sujeito na incerteza que dá sentido e forma à angústia. Mas o toque romântico, 
que definitivamente não é o de Machado de Assis, está na possibilidade de contornar e vencer a angústia, mantendo e vivificando a certeza (ideal, sublime) do reencontro. O mundo de Machado, porém, é o do corte abrupto desta certeza - figurada pela esperança que teima em rebrilhar - de um encontro.

Convém então refletir sobre como o entrecho e a música do Fidelio podem ter entrado, meio às avessas, no universo composicional do Memorial de Aires. Insisto numa ausência inevitável aqui - a música, cuja presença neste ensaio limita-se a descrições imensamente pobres, se confrontadas à riqueza da própria ópera - porque penso que o enlace do canto está no centro da cena do Memorial (Fidélia e Tristão a olhar-se e, em vários momentos, um a cantar, outra a tocar piano), embora saibamos que a fidelidade não é, ali, mais que a máscara a ocultar o real desejo da jovem, que supomos ("suposição" que devemos ao narrador) desejosa de abandonar o primeiro marido, por saber que ele não se esconde mais em canto algum. No Memorial de Aires, tudo já se inicia, muito placidamente, num cemitério.

Resumindo, ali onde deveríamos encontrar - se nos mantivéssemos no plano do Fidelio - o canto que permite ver, ouvir e sentir a comunhão dos esposos, ao invés encontramos - no plano do Memorial de Aires - a narrativa oblíqua de uma relação que se desenrola a partir, precisamente, do abandono daquele empecilho original que é a um só tempo o corpo e a memória do marido morto. Então o canto, nem tão sublime, mais mundano em todo caso, aponta para a libertação e o abandono da fidelidade que a ópera celebra. Por baixo da máscara que porta, a Fidélia de Machado de Assis, ou do conselheiro Aires, tem outros desejos, que o entrecho do Fidelio não suportaria.

Ainda uma vez lembremos, no caso da ópera, a força da ligação que não pode romper-se, e que o canto, mais que expressar ou sugerir, acaba por assumir, como se a própria união fosse um canto. Eu sugeria, páginas atrás, as hélices cruzadas que poderiam porventura simbolizar os cantos de Marcelina, Leonora, Rocco e Jaquino. A metáfora é certamente insuficiente, quando se trata do dueto final do Fidelio.

O canto é a união, a união é o canto. É o que sugere Daniel Banda (1999, p.92-3), na bela passagem em que se refere ao oboé que, na primeira cena do segundo ato do Fidelio, acompanha o delírio de Florestan, tocado, no escuro da cela, pela visão redentora de sua esposa:

Le thème conjugal est aussi dans la conjugaison des voix. Les voix séparées doivent à nouveau être liées. Mais la voix est déjà un lien. Le hautbois est autre chose que le motif substitutif et artificiel d'un personnage. Le hautbois est la présence - musicale - aimée qui vient lier ce qui est encore dispersé: les amants, le passé et le présent. Dans la tradition classique, le hautbois sert à introduire la parole humaine. [...] Le hautbois est le lien sonore qui unit Florestan et Leonore dans la séparation, affirme leur identité et les conduit l'un vers l'autre, puis vers tous les autres: un principe de liaison, un principe d'unité et un principe symphonique. Rêve de complicité. Rêve d'une mélodie ininterrompue. Legato. 
No legato encontra-se a chave da união, mesmo e sobretudo se nos transportamos para o dueto final. Mas, na cena a que se refere Banda, Florestan vê apenas o que está ausente: Leonora. A imagem o consola, como a todo amante. Aí o canto, como verdadeira exclamação de júbilo e dor, permite manter o contato, conduzindo, imaginariamente, um amante ao outro. A cena inicial do segundo ato prenuncia o momento glorioso do reencontro, quando, após ter-se conduzido ao esconderijo por meio de suas artimanhas de heroína mascarada, Leonora chegará a Florestan.

Retomando os passos, Fidelio é a máscara, embora atrás dela descanse a essência que lhe corresponde à perfeição: a fidelidade sem máculas. Mas o júbilo do reencontro somente é possível porque Florestan se guarda no fundo do castelo sombrio que constitui o cenário do Fidelio.

Aqui, tomados "não sei por que inspiração maligna", poderíamos modificar o cenário e, assistidos pelo poder - não menos maligno - do escritor de decidir a vida e a morte de seus personagens, poderíamos por fim livrar-nos de Florestan. Eis a equação: transforme-se o castelo espanhol no cemitério de São João Batista, no Rio de Janeiro. Acrescente-se porém o toque maligno: o marido agora é morto.

\section{Luzes e sombras}

Morto Florestan, extingue-se a chama, figurada naquele brilho oscilante, mas resistente, da esperança. Arriscando-me por um terreno decididamente metafórico, penso que luz e sombra possam fornecer uma chave para a compreensão do que se dá no Memorial de Aires, levando-nos a uma imagem por meio da qual, suponho, podemos acercar-nos do núcleo dubitativo que dá tom ao relato: refiro-me à possibilidade de pensar o Memorial como uma narrativa baça.

No Fidelio, a tensão dramática se estabelece no contraste entre a obscuridade em que está mergulhada a alma do prisioneiro e a chama débil que, a despeito de tudo, mantém-se. Jogo de luz e sombra para ambos os esposos, aliás: Leonora enfrenta com tenacidade o desalento que adviria da perda de sua derradeira esperança, e seu canto constitui a fonte que reativa o brilho, no instantechave em que nos sentimos mais próximos do apagamento, quando tudo parece perdido, prestes a consumir-se na negrura do castelo e do desespero; Florestan tem, no fundo da cela escura, a visão da esposa, cuja presença luminosa o seu próprio canto, entrelaçado aos sopros distantes, atualiza, logo no início do segundo ato. A cena, arrepiantemente bela, sugere que toda a história sustenta-se no jogo de presença e ausência, próprio aos namorados. O resultado, bem romântico, é que oscilamos entre a mais completa escuridão e o mais luminoso dos dias. O reencontro, porém, e com ele o entrelaçamento das almas, posta-se no horizonte, e ali permanece, ditando a espera e marcando a cadência da história. Vemos então a potência narrativa no Fidelio: combatida a escuridão ameaçadora, contra o fundo negro fulge, gloriosa, a própria fidelidade.

Em tal universo há uma chama, um norte, e a única aposta possível baseiase na crença do reencontro. Não há desvio, nem pode haver dúvida legítima. $\mathrm{O}$ 
perigo de que a chama se consuma é o motor da ação heróica, e os personagens se destacam, em contornos claros, contra um fundo escuro, numa sorte de otimismo exacerbado em relação à matéria humana - eis aí a herança iluminista que, a despeito de todas as suas peculiaridades, o romantismo de Beethoven sublima.

Se quiséssemos, entretanto, filiar Machado de Assis a certas correntes filosóficas do século XVIII, seria sobretudo a autores como Voltaire ou Helvétius que chegaríamos; ou talvez, voltando ainda mais no tempo, é no século XVII francês que encontraríamos algumas de suas fontes mais poderosas, como La Rochefoucauld e Pascal. ${ }^{20}$

Já se viu como a dúvida pode instaurar-se numa pequena observação do Memorial de Aires. Nas suas constatações aparentemente mais simples, flagramos o espírito cético a corroer a certeza sobre a qual repousa toda esperança na redenção humana. Trata-se, em chave teológica, de observar o homem como criatura caída, entregue ao mundo, desassistido de um poder remissor. Uma das caracterísiticas que podem unir perspectivas diversas como as de La Rochefoucauld e Pascal é o fato, abominável para qualquer otimista, de que a Providência se posta ao longe, misteriosa, urgente (para a angústia pascalina, mais que para a moral mundana de La Rochefoucauld) e ao mesmo tempo inacessível aos homens. Antes que os filósofos das luzes laicizassem completamente a visão que possuímos do tempo e da salvação, jogando no colo do indivíduo a responsabilidade pela ação e pelo futuro, os moralistas franceses punham em dúvida o alcance e a transparência de toda e qualquer ação, e de suas conseqüências. "A essência turva do homem": assim Augusto Meyer (1947, p.37) referia-se ao "alvo" de Machado de Assis, localizando-o abaixo da "máscara superficial", dos "gestos e palavras".

Trata-se, ainda aqui, de um jogo de luz e sombra, embora completamente diverso daquele que notamos no Fidelio. Lá, o foco recai sobre a criatura humana como uma luz que, sabemos de antemão, não fará mais que iluminar e confirmar o poder de dobrar e controlar o destino. Contra todas as previsões, contra o entorno hostil, o herói rompe os grilhões, como um Prometeu que, findo o poder dos deuses, se libertasse por meio de sua própria força e astúcia. De qualquer forma, a potência do ato humano reclama o herói inteiriço, cuja fratura (a máscara, a identidade cindida) é artificial, isto é, sabemos que, na verdade, Fidelio é e sempre será a fiel Leonora. A fratura, no caso, serve apenas ao entrecho, às peripécias que levam ao momento de revelação, que está na coincidência entre a máscara e a essência. Em outros termos, estamos diante de um mundo ora claro, ora luminoso, mas refratário aos meios-tons, como se a zona cinzenta que separa aquilo que se declara (a máscara) daquilo que é (a essência) simplesmente não existisse.

Nessa zona cinza, Machado de Assis tece sua narrativa, especialmente no caso do exercício de análise moralista (no sentido de La Rochefoucauld ou Pas- 
cal) que é o Memorial de Aires. Entre a máscara - Fidélia no cemitério e nos saraus, calculando gestos e medindo palavras - e a essência - a zona turva do desejo que desconhecemos, mas podemos pressentir - desliza a pena do escritor, movida por uma paixão analítica parecida àquela do século XVII, ainda que "o" século XVII não seja unívoco, pois que nele se dá, por exemplo, o embate entre, de um lado, o ceticismo redivivo na França que emergia das guerras de religião e, de outro, já a anunciar a crença na transparência analítica, o universo cartesiano com todas as suas promessas e quimeras.

Narrativa baça, porque sobre a escrita pesa a desconfiança no gesto e na máscara, mergulhando tudo num entretom que esconde e dissimula os contornos. Os personagens não são mais, como no Fidelio, inteiros, e o mundo não mais se revela no contraste dos caracteres que se desenham, inequívocos, contra o fundo da narrativa. A fixação do gesto, dos movimentos e das palavras no $\mathrm{Me}$ morial de Aires é uma arte de outra natureza, porque a crença inicial na criatura humana se manchou e a dúvida se instalou, abrindo espaço para que a própria ação não mais contenha, em seus inícios e em sua forma, o segredo do caminho que tomará o sujeito. Ao contrário, o sujeito da ação passa à condição de personagem numa trama de desconfiança, porque os seus gestos a rigor nada dizem, ou antes, dizem o que não se diz.

A dimensão da aposta se torna, nesse momento, crucial. Como em Pascal, é preciso apostar: já estamos "embarcados”, desde que não há instância alguma, humana, capaz de desvendar o curso da ação, e o sentido por que se guiam os homens. Quero crer que estejamos aqui diante de um ponto curioso, porque a arte de Machado de Assis se alimenta, se não me engano, da desconfiança profunda e original que torna o universo das ações humanas uma gigantesca mascarada, em meio da qual todo e qualquer julgamento - sobre o caráter - não pode ser senão uma aposta, afinal não sabemos, de fato ("não quer dizer que..."), o que está comandando as ações. Até aí, poderíamos reclamar-nos ainda no terreno que pisaram os moralistas clássicos franceses, para os quais o único móbil dos homens é o amor-próprio, ou o apetite de conservação que nos faz atuar e brilhar a qualquer custo. Porém, seria ingênuo, ou quando menos insuficiente, supor o traço moralista onipresente e conclusivo em Machado de Assis. Há um elemento mais na antropologia machadiana, que é a possibilidade de tornar risível o otimismo das luzes (pois não há algo de panglossiano no emplasto antihipocondríaco de Brás Cubas, ou no Humanitismo do Quincas Borbas?), ou de simplesmente relativizar-lhes as promessas, buscando ao século XVIII sua veia mais satírica. ${ }^{21}$

Ainda que o Fidelio possa, em alguns momentos, mergulhar-nos num desespero atroz, sabemos que a apoteose nos aguarda, e que, com ela, virá a redenção dos valores que perigam - como a fidelidade. Não será casual se a literatura romântica se nutriria tão freqüentemente dos triângulos amorosos e das traições mais ou menos escabrosas: fala-se de um mundo em que as relações de sangue 
já não são bastantes, e em que a fidelidade se torna uma matéria propriamente moral. Não se trata de uma preocupação exclusivamente burguesa, é claro, mas o fato é que a manutenção da família, da linhagem e da fortuna, estabelece-se em torno a relações que parecem poder desfazer-se a qualquer instante. Há aí uma instabilidade incontornável. ${ }^{22}$

Talvez possamos entender o entrecho do Fidelio como uma resposta, ainda esperançosa, a um mundo que, para Machado de Assis, já ia ruindo, deixando atrás de si, aliás, umas ruínas bem modernas. Basta pensar no contexto - Fidélia como a herdeira de uma ordem patriarcal que se desfazia e se reconfigurava, a escravidão que saía de cena, a urbanização que roubava toda a cena, a condição feminina despontando como questão - e veremos que a "fidelidade" envolve mais que o simples compromisso com valores vetustos. $\mathrm{O}$ mundo de Machado de Assis, cifrado como é, põe em movimento, no plano ficcional, o desencanto com as promessas civilizadoras, com os valores, com as explicações canônicas e otimistas da sociedade burguesa. É já um sopro moderno, embora a potência lhe venha, amiúde, daquela literatura desencantada do século XVII.

Trata-se de um ceticismo entre moderno e clássico, que torna risível o discurso ideológico do tempo, tanto quanto se vale do riso quase intemporal sobre a condição humana. ${ }^{23} \mathrm{O}$ compromisso entre os homens, suas relações e expectativas mútuas não são mais ditados por valores transcendentes e imutáveis. Ao contrário, algo se foi, e o mundo que se anuncia - ou que resta, depois da dissolução dos valores - é demasiado confuso, ou intrincado, para que se torne possível ainda, como talvez o fora antes, compreender completamente o curso da ação humana. O devir é um mistério, e o caminho dos homens, inexato e tortuoso, convida à aposta: para onde irá o sujeito?

Nesse momento, Pascal deixa de ser útil, porque a aposta não se volta mais para a transcendência, para a "distância infinita" que nos separa de Deus. Ao contrário, a observação do mundo requer a análise milimétrica dos gestos, já que toda a vida humana se resume a um cerrado espaço social, como se a promessa da redenção tivesse sido esgotada. Resta um universo em que ainda operam as paixões ("La durée de nos passions ne dépend pas plus de nous que la durée de notre vie”, sugere La Rochefoucauld [max.5, 1980, p.403]), embora o cálculo se imponha e procure, nem sempre em vão, controlar o devir.

$\mathrm{O}$ traço mais assustador do Memorial de Aires pode ser a trama maquiavélica de Fidélia e Tristão, que apenas pressentimos, oculta e poderosa, a atuar e a manipular os personagens como se fossem joguetes inconscientes de uma intenção inconfessável.

A profunda consciência sobre os atos, que a narrativa não chega a explicitar, é o dote raro dessa Fidélia que, ao contrário do seu duplo romântico (Leonora), abandona as cordas que a prendem ao lastro do passado, lançando-se num futuro que desconhecemos, e que o narrador, não se sabe movido por que potência maligna, se antiga ou nova, deixa na sombra. ${ }^{24}$ 


\section{Não parece um anjo?}

Há algo de indizível, ou de imprevisível, nos atos de Fidélia. Entretanto, a imprevisibilidade, e com ela tudo aquilo que não se pode dizer, não vai servir a compor um caráter sublime. No diário de Aires, sabemos a gota de fel que se mistura à tinta do escritor: no imprevisível se expressa apenas a dúvida, da qual se alimenta o desejo do diplomata, já incapaz de amar (aí os famosos versos de Shelley emendados pelo conselheiro - "Eu não posso dar o que os homens chamam amor... e é pena!" [MA, 25 de janeiro de 1888]), mas profundamente interessado em observar.

Vejamos a cena do dia 29 de maio de 1888, quando Aires pela primeira vez se acerca com mais vagar de Fidélia. Como de costume, estamos numa reunião na residência dos Aguiares, onde se vê a dama cujo gesto "era cheio de graça, sem perder a tristeza do estado". Já aí, deparamos (guiados pelo conselheiro) com o delicado balanço entre a compostura da viúva e a graça da jovem. Ao referir a "tristeza do estado", Aires deixa correr o fel, fazendo que a "tristeza" se associe sub-repticiamente ao "estado" social da viúva. Assim vistas as coisas, jamais saberemos se a tristeza é sincera. Ou, no registro do memorial, a própria sinceridade não se desvincula do plano social e das aparências que se mantêm.

Depois de uma conversa amena ao pé da janela, observando a Baía de Guanabara, Aires comenta com a viúva que ouvira louvadas suas qualidades de pianista. "São impressões de amigos", diz ela. O que segue é um primor de dissimulação e graça, e vale a citação completa:

Depois confessou-me que há muito não toca, e provavelmente esquecerá o que sabe. Talvez não fosse sincera nesta conjetura, mas tudo se há de perdoar ao ofício da modéstia, e ela parece modesta. Guiei a conversação de modo que mais ouvisse que falasse, e Fidélia não se recusou a essa distribuição de papéis. Disse pouco de si e muito da gente Aguiar. Neste ponto falou com algum calor; não me deu coisas novas, mas o que sentia dos dois foi expresso com alma. Contou-me até que entre D. Carmo e a mãe dela achava semelhanças que lhe faziam lembrar alguma vez a finada, - ou seria simplesmente a afeição que aquela lhe tem. Enfim, separamo-nos quase amigos.

Não repeti à gente Aguiar o que a seu respeito ouvi à viúva Noronha; falei a D. Carmo nos talentos musicais da moça, e ela me confirmou que a viúva está disposta a não tocar mais. Se não fosse isso, pedia-lhe que nos desse alguma coisa. Ao que eu respondi:

- A própria arte a convidará um dia a tocar em casa, a sós consigo.

- Pode ser; em todo caso, não a convidarei a tocar aqui; o aplauso podia avivar-lhe a saudade - ou, se a distraísse dela, viria diminuir-lhe o gosto de sofrer pelo marido. Não lhe parece que ela é um anjo?

Achei que sim; acharia mais, se me fosse perguntado. D. Carmo crê na reconciliação dela com o pai, e nem por isso receia perdê-la. Fidélia saberá ser duas vezes filha, é o resumo do que lhe ouvi, sem entrar em pormenores nem na espécie de afeição que lhe tem. Do que ela me disse acerca do "gosto de sofrer pelo marido", concluo que a senhora do Aguiar é daquelas pessoas para quem a dor é coisa divina. (MA, 29 de maio de 1888) 
O diálogo é todo ambivalências. Pode-se dizer que o conselheiro encontra uma interlocutora à sua altura, pois ambos desempenham com perfeição $\mathrm{e}$ alma os papéis que representam, Aires curioso ("guiei a conversação de modo que mais ouvisse que falasse") e Fidélia modesta ("disse pouco de si e muito da gente Aguiar"). A modéstia é o "ofício" da jovem viúva. Quando, no Fidelio, poderíamos supor que Leonora "não fosse sincera", e que o "gosto de sofrer pelo marido" fosse mera afetação, como venenosamente sugere o narrador em relação a Fidélia?

Curioso é que Aires atribua a seus personagens, malgré eux, o papel de deflagradores da suspeita. D. Carmo evita convidar Fidélia ao piano, para não “avivar-lhe a saudade". Em seguida, porém, o conselheiro ouve à virtuosa Aguiar que, de fato, ela não convidava a viúva a tocar piano para evitar que esta se "distraísse" da saudade, e se lhe diminuísse o "gosto de sofrer pelo marido". A conclusão é graciosa: talvez Carmo tivesse a dor por "coisa divina".

A divinização da dor, no caso, seria a manutenção do laço sagrado que une Fidélia ao morto. Procurando manter e estender o luto da jovem, D. Carmo sabe (embora jamais vá dizê-lo) que mantém ao pé de si a viúva, que a essa altura do Memorial ainda não fora cortejada por Tristão. O narrador divide com a boa Aguiar o peso da suspeita, pondo na boca da personagem aquilo mesmo de que ele quer convencer-nos: o luto, e com ele a fidelidade, poderiam interromper-se a qualquer instante. Não fosse assim, por que a velha Carmo evitava insistir que Fidélia tocasse piano, temerosa de que se despertassem nela sentimentos outros que o respeito ao luto?

Mas Fidélia parece sempre à frente dos demais, no esforço por tramar seu próprio destino. Suas intenções, pode sugerir o conselheiro, parecem (é fundamental que pareçam) pautadas pela lealdade simultânea ao finado marido e à mãe postiça. Não à toa, ao cabo do livro ela abandonará ambos, sem que sequer saibamos se leva consigo a menor sombra de remorso. Vamos sentindo, já nesse início de narrativa, o poder da dúvida: perguntado se Fidélia não se parecia a um anjo, o conselheiro achou "que sim", mas "acharia mais", se lhe "fosse perguntado"...

Aires provoca e em seguida silencia. No silêncio, naquilo que ele não diz, está toda a verdade. Talvez a paixão do conselheiro por Fidélia não seja, finalmente, apenas ideal ou sublime: a viúva vai conquistando aos poucos - e com que arte! - aquilo que ele próprio é incapaz de alcançar, isto é, o amor em sua dimensão sensitiva. Sendo assim, podemos lembrar a suposição inicial de que, como em outros momentos da narrativa machadiana, a escrita é a compensação da impossibilidade de realização do narrador. $\mathrm{O}$ foco narrativo se estabelece a partir de uma incapacidade. No caso do conselheiro Aires, a aposta é a realização compensatória do desejo que ele sente pela viúva, desde o início. Já a narrativa mesma é a posta em cena daquele desejo, como se a ficção servisse a compensar uma perda, que é a perda do objeto querido. Ou talvez, para lançar-nos numa breve especulação teórica, a ficção fale da perda do objeto literário. 
Um dos possíveis índices da ficção machadiana (do "segundo Machado", como às vezes se diz) é a escrita que se defronta com a perda ou a falência das promessas de um mundo que já passou. Sendo impossível voltar atrás, nada restaria senão escrever, ou seguir escrevendo. O conselheiro Aires é o resultado dessa ficção que teima em retratar o que se desfaz, como se um mundo em ruínas forcejasse por vir à página, reclamando o cronista melancólico e safo que lhe adivinhe os contornos sempre desfeitos.

Embora nem sempre o efeito seja sombrio, freqüentemente o narrador parece pronto a deixar a cena (Brás Cubas levaria ao paroxismo a possibilidade de retirar-se), como se ameaçasse abandonar um mundo cujo sentido ele foi incapaz de recompor. As conseqüências para a escrita são importantes porque, sobretudo no caso do Memorial de Aires, a própria recomposição do mundo pela narrativa revela-se problemática, e o olhar onisciente do narrador cede ao seu próprio desejo ainda não realizado, podendo resultar daí um olhar viciado, como o de um apostador profissional.

Enquanto nas Memórias póstumas de Brás Cubas o que vemos são as cabriolas narrativas do herói, aliás desprovido de qualquer heroísmo, no Memorial de Aires a narrativa é mais morosa, obedecendo a uma singular economia do desejo que, ao atuar, traz à página a personagem, para em seguida submetê-la à descrença diabólica do autor do diário.

O conselheiro parece viver do balanço entre a aproximação e o afastamento, como se a proximidade do objeto desejado o obrigasse a conter todo ímpeto, que ele trata de canalizar para a escrita, transformando Fidélia em refém ficcional de seu desejo de narrador: no conto de Aires, a viúva encontra-se sempre na iminência de trair o morto. ${ }^{25}$

O resultado literário é extraordinário, tendo um alcance teórico considerável, já que a incapacidade do narrador fictício em tocar o objeto desejado é também, simultaneamente, a impossiblidade da própria escrita em tocar e recriar seu objeto em sua suposta inteireza.

Em termos mais simples, o referente da escrita, como o referente do desejo do narrador, se esvai a cada momento em que o escritor crê acercar-se dele. Portanto, a representação não se sustenta mais na fidelidade a um mundo exterior ao próprio ato de escrever. Ao contrário, é pela escrita que eu me aproximo do objeto, embora o que eu escreva não sirva senão como o rastro, ou o testemunho de um desejo irrealizado de aproximação a que a ficção dá forma. $\mathrm{O}$ resultado do que se escreve é fiel, portanto, tão-somente ao narrador, cuja voz recompõe um mundo que é, ao fim, apenas uma construção compensatória, isto é, nem mais nem menos que a própria escrita.

Abandonemos, porém, o círculo em que se encerram tais especulações teóricas, e voltemos a Aires e sua história, a fim de verificar como a fidelidade é uma peça central que, posta em xeque, compromete e mobiliza o desejo difuso do nosso escritor ficcional. 


\section{Fim: um latido filosófico}

Num "capítulo" incomum por sua larga extensão - o relato do dia 18 de setembro de 1888 -, o conselheiro Aires retorna da casa dos Aguiares com um cão na cabeça. Em certo sentido, trata-se de mais um cachorro a repor a figura do filósofo, o que não soará completamente estranho a um leitor de Machado de Assis. ${ }^{26}$

Nesse caso, Aires recém-ouvira do casal Aguiar, em especial da senhora, o discurso angustiado de quem se pressente abandonado: D. Carmo lia cada gesto de Tristão e sabia que ele em breve partiria para a Europa, embora ainda não pudesse adivinhar que Fidélia o acompanharia, abandonando os padrinhos, os quais ficariam no Rio de Janeiro velando a si próprios em sua solidão, como pode sugerir a melancólica última cena do Memorial. ${ }^{27}$

O cachorro vem à baila porque Aires, logo antes de deixar a casa dos amigos, refere, com sua discreta indiscrição, a história que ouvira sobre o cãozinho que os Aguiares uma vez possuíram e trataram com desmedido carinho, até o dia em que o bicho morreu e eles o enterraram no jardim. O cão, fiel por metonímia, nunca os abandonara, com eles ficando até a morte. A conversa daquela noite se iniciara, aliás, com a observação funesta de D. Carmo, para quem Tristão voltaria, quando muito, "para ver as nossas covas".

O cão impressiona, e os próprios sentimentos de amor ao animalzinho, da parte do banqueiro Aguiar, parecem estranhos ao conselheiro Aires:

Apesar de não ser dado a melancolias, nem achar que o ofício de banqueiro vá com tais lástimas, separei-me dele com simpatia. Vim pela Rua da Princesa, pensando nele e nela, sem me dar de um cão que, ouvindo os meus passos na rua, latia de dentro de uma chácara. Não faltam cães atrás da gente, uns feios, outros bonitos, e todos impertinentes. Perto da Rua do Catete, o latido ia diminuindo, e então pareceu-me que me mandava este recado: "Meu amigo, não lhe importe saber o motivo que me inspira este discurso; late-se como se morre, tudo é ofício de cães, e o cão do casal Aguiar latia também outrora; agora esquece, que é ofício de defunto".

Pareceu-me este dizer tão subtil e tão espevitado que preferi atribuí-lo a algum cão que latisse dentro do meu próprio cérebro. Quando eu era moço e andava pela Europa ouvi dizer de certa cantora que era um elefante que engolira um rouxinol. Creio que falavam da Alboni, grande e grossa de corpo, e voz deliciosa. Pois eu terei engolido um cão filósofo, e o mérito do discurso será todo dele. Quem sabe lá o que me haverá dado algum dia o meu cozinheiro? Nem era novo para mim este comparar de vozes vivas com vozes defuntas. (MA, 18 de setembro de 1888)

A passagem, seja ainda críptica, deixa logo ver alguns dos elementos da história dos futuros noivos e de seus padrinhos: os mortos, os corpos velados, vozes vivas e vozes defuntas e, por fim, a lealdade ao que já passou. O foco está num mundo que se deixa, como o latido longínquo na rua deserta pode sugerir. Mas que som impertinente é esse, que teima em dizer coisas que já estão na cabeça do conselheiro? 
O cão dos Aguiares "latia também outrora; agora esquece, que é ofício de defunto". Temos aqui a dimensão - tão presente para um Machado de Assis doente e solitário, viúvo ele mesmo quando escreveu estas linhas - do tempo que passa e também abandona os vivos, condenando-os ao esquecimento completo, pois que um dia os que ficam também partirão, e não restará nada, nem memória do que esteve um dia sobre a terra. "Não há memória dos antepassados, e também aqueles que lhes sucedem não serão lembrados pelos seus descendentes", nas palavras do Eclesiastes $(1,11){ }^{28}$

É sempre tentador - e porventura equívoco - criar um curto-circuito que atribua a Aires aquilo que o próprio Machado de Assis escrevia, como se os evidentes traços do alterego fossem bastantes para apagar as linhas que separam autor e narrador. Deixemos a tentação de lado, para notar que, no Memorial de Aires, o foco recai sobre um mundo que vai ficando para trás. ${ }^{29}$ Ao mesmo tempo, o narrador se posta, não sem prazer, nas fronteiras de um universo evanescente, no limite do desaparecimento, surgindo meio livremente aqui e acolá na cena, não de todo perceptível, um pouco à maneira de um fantasma que se introduz onde quer, quando quer.

Há conseqüências interessantes aí, uma vez que não mais apenas o objeto da literatura ameaça sumir. O próprio foco narrativo, nesse caso, é instável, captando nossa atenção de forma tão mais decisiva quanto mais a voz narrativa se encontre na iminência de desaparecer - como no fading radiofônico, que a um só tempo nos encanta e angustia. ${ }^{30} \mathrm{~A}$ voz do conselheiro - rarefeita como convém a alguém que se chama Aires - alinha-se, portanto, ao latido filosófico que fica lá atrás a rezar os ofícios de mortos e vivos, notando que os vivos lembram, enquanto os defuntos esquecem. É uma voz que se ergue no limite do esquecimento, votada ao silêncio do diário.

Vemos surgir, na cena citada, mais um morto: dessa vez, um cão vivo lembra o cão morto. Convém então perguntar: qual defunto passa pela cabeça de Aires? Em outros termos, que defunto o conselheiro pretende evocar, ou calar? Curioso que o ofício de esquecer seja atribuído ao cão morto. Afinal, trocando os cães às pessoas, podemos supor que os vivos, por vivos, é que esquecem. Os mortos são mortos, nem esquecem nem lembram: são esquecidos, apenas.

O cão que late sua filosofia poderia ser visto como um demônio, lembrando a Aires (e ao leitor, obviamente) que os mortos vão longe, e que é, no entanto, difícil separar-nos deles. Toda a provocação está na solércia do cão vivo, a sugerir que os mortos esquecem. Isto é, quando desaparecem os cães (e os maridos, poderíamos já supor), não haveria muito que preocupar-se, porque o esquecimento toma conta de tudo. Dizer que o morto esquece é, sem dúvida, provocador, mas é também liberador. Afinal, a acreditarmos na filosofia canina, deveríamos deixar que o defunto descanse, para que continuemos latindo do lado de cá. Muito cômodo, então, imaginar que o morto esqueça, pois assim nos liberamos da culpa do nosso próprio esquecimento. 
Les morts vont vite, escreve o conselheiro depois da morte do leiloeiro Fernandes, numa sentença muito apropriada a Fidélia, que parece esforçar-se por deixar o marido morto (MA, 21 de maio de 1888). ${ }^{31}$ Como em outros momentos no memorial, o episódio do leiloeiro traz à página a preocupação com $\mathrm{o}$ esquecimento dos finados, e a sensação de que qualquer gesto diante da morte é um desplante um pouco ridículo.

Em 23 de maio de 1888, dias depois da morte de Fernandes, lemos, pelos comentários de Aires sobre mana Rita, que Fidélia "mordera" uma pessoa. No dia seguinte, ao meio-dia, nas conversações "do papel para o papel”, o conselheiro relata que, naquela manhã, a jovem viúva lhe aparecera em sonho, entregando-se a ele, velho sexagenário, "desenganado e guloso". ${ }^{32}$

Les morts vont vite, e eis que a viúva "morde" aqui e ali, invadindo até os sonhos alheios. Há algo de brutal na imagem de uma Fidélia a dar-se por fim ao mesmo mundo que o marido deixara. Não se trata de um julgamento moral, porém. Apenas noto a importância de que a viúva se entregue, abandonando um passado em que se incluem e ficam, votados ao esquecimento, todos os velhos: Aires, sua irmã, o casal Aguiar. A brutalidade não está no ato moralmente condenável de trair o marido, que aliás está morto, mas sim na traição que os vivos perpetram, pelo simples fato de que vivem. Viver é, afinal, sobreviver aos que ficam pelo caminho, e ensina a filosofia prática de Fidélia que é melhor esquecêlos, nisto corroborada pelos latidos filosóficos daquele cão impertinente.

Retomando os fios, para dar cabo deste ensaio, resta lembrar e realçar que a traição de Fidélia não é apenas um drama moral. Deixar o passado pode ter, no "segundo Machado", um sentido peculiar, já que o mundo que os jovens noivos (Tristão e Fidélia, finalmente juntos) deixariam para trás é também o único mundo que a narrativa machadiana mobilizava. Sabemos que a prosa de Machado de Assis raramente trabalha outro solo que a sobrevivência do Império, e a permanência, século adentro, das relações estabelecidas no seio daquela ordem social, aí incluído, é claro, o universo - ora oculto, ora evidente - da escravidão e de suas heranças. ${ }^{33}$

Deixa-se o mundo, como se deixa a escrita: na esperança de que um vento tome tudo de assalto e leve, para sempre, o que é "caduco" e "extinto". O paradoxal, ou quando menos assustador, é que o mundo que se construirá então não está ao alcance das nossas vistas. Quando vier a se constituir - se vier a constituirse -, o mundo novo estará num outro ponto, além do mar e além do que pode desvendar a escrita de Machado de Assis.

\section{Notas}

1 Capturar o desejo do narrador, para denunciar-lhe o ponto de vista, bem como as inclinações que conformam a narrativa, é procedimento crítico que mereceria toda uma genealogia. Contudo, penso aqui tão-somente em dois momentos da crítica, quando o olhar masculino do narrador de Dom Casmurro é flagrado, e quando os interesses de 
classe de Brás Cubas são destacados e avaliados. Cf. Caldwell (1960, 2002); Schwarz (1990).

2 Sugere-o José Paulo Paes, lembrado por Alfredo Bosi (1999, p.143).

3 Comentando as observações de João Adolfo Hansen, de que Machado trabalha as ruínas de um tempo pré-moderno, Michael Wood (2002) conclui: "This is not a search for lost time but a memorial of how lost it is, and even the memorial may be a fiction. Walter Benjamin, in his essay on the storyteller, wrote that a proverb is a ruin which stands on the side of an old story', and Machado, we might say, wrote ironic narrative proverbs which know their own helplessness. Nothing more modern than a ruin in this sense".

4 É o que encontramos na interessante e imaginativa interpretação de John Gledson (1985, p.121-50; 1986, p.215-55). Sobre a busca do enredo no último romance de Machado de Assis, um exemplo curioso da dificuldade de suportar o seu entrecho rarefeito encontra-se na contracapa da edição escolar mais comum hoje, no Brasil, do Memorial de Aires: "Fidélia é tudo o que tem aquele melancólico casal de velhos. É a forma que encontraram para diminuir sua solidão. Mas as coisas mudam rapidamente. O que pode acontecer se Fidélia resolver casar?" (cf. Assis, 1999). Trata-se de escamotear a ausência do enredo novelesco no romance, como se o leitor médio (ou o "público-alvo", segundo o sugestivo jargão mercadológico) não pudesse suportar um texto em que, no fundo, nada de "emocionante" acontece. Lembro, a propósito, a tirada espirituosa de Salvador de Mendonça, na crítica coeva que Hélio Guimarães recentemente levantou e estudou: "Alguém já me disse que o livro não tinha enredo, e eu the respondi que o mister dos velhos não é fazer enredos, mas desenredal-os" (cf. Jornal do Commercio, Rio de Janeiro, 6.9.1908, p.1, apud Guimarães, 2004, p.467).

5 Valho-me da edição da Obra completa, organizada por Afrânio Coutinho (cf. Assis. 1992, v.1, p.1115-6). Doravante, referirei o Memorial de Aires apenas pela sigla "MA", seguida da data do diário. Nesse caso, 8 de abril de 1888.

6 Embora o embate entre os apostadores não se dê nas alturas, vale lembrar a sugestão de José Paulo Paes (1985, p.25-7), para quem a aposta prefigura a experiência da realização vicária por meio da qual Aires se acercará de Fidélia, portando - aí sim, mefistofelicamente - "duas almas": uma jovem e ambiciosa, outra sexagenária e prudente.

$7 \mathrm{O}$ veneno encapsulado e nunca completamente liberado pode porventura lembrar a advertência de Alfredo Bosi (1999, p.142) em relação ao estilo clássico, que é uma outra forma de conter os excessos destruidores: "A análise do justo meio na teoria e na prática de Aires corre o sério risco de ficar tão rente à pele do estilo machadiano que ignore, ou apenas subentenda, a força dos extremos postos em tensão. É preciso ver o compasso em movimento. Enlevados pela cantante harmonia de Mozart, podemos esquecer que ela resultou de uma conquista da linguagem musical sobre o torvelinho de Eros e Pathos, que desejariam arrastar o compositor ao grito, ao choro, ao riso, ao silêncio. A classicidade tranqüila da última demão tenta esconder o que lhe deu a vida e a forma".

8 Comentando, em carta a Joaquim Nabuco, o livro de aforismos que este então publicara, Machado de Assis (1992, v.3, p.939) escreve, em agosto de 1906: "Desde cedo, li muito Pascal, para não citar mais que este, e afirmo-lhe que não foi por distração. Ainda hoje quando torno a tais leituras, e me consolo no desconsolo do Ecclesiastes, acho-lhes o mesmo sabor de outrora. Se alguma vez me sucede discordar do que leio, sempre agradeço a maneira por que acho expresso o desacordo". 
9 Piso aqui um terreno difícil, que divide a crítica e cria cisões por vezes incontornáveis, quase sempre relacionadas ao relevo dado aos elementos históricos na interpretação da escrita machadiana. A crônica será, evidentemente, um dos focos mais notáveis da polêmica que posiciona, em campos opostos, críticos como John Gledson (1985) e Alfredo Bosi (2004). De Gledson, tomo como exemplo, embora menos recente, as introduções críticas às crônicas de Machado de Assis (cf. Assis, 1990, 1996).

10 Leia-se, por exemplo, o pensamento 78 (ed. Sellier) de Pascal (1992, p.335) sobre a "imaginação", de que destaco o seguinte fragmento: "L'imagination dispose de tout. Elle fait la beauté, la justice et le bonbeur que est le tout du monde. Je voudrais de bon coeur voir le livre italien dont je ne connais que le titre, qui vant lui seul bien des livres, Dell'opinione regina del mondo. J'y souscris sans le connaître, sauf le mal, s'il y en a".

11 Penso na interessante maneira por que Lucia Serrano Pereira (2004) se apropria da noção benjaminiana de constelação, em seu belo estudo sobre o Dom Casmurro. Suas observações sobre Capitu e os olhos que essa deita ao defunto Escobar, diante de um Bento Santiago já mordido pelo ciúme, fazem pensar também na mira do conselheiro Aires, que se volta para a jovem Fidélia e para seus gestos diante do túmulo do marido. É verdade que o resultado é diverso, já que o conselheiro se segura nas bordas de sua ficção, simulando uma alegre indiferença, enquanto Bento simplesmente naufraga, em sua angústia de homem traído.

12 Vale a pena lembrar não apenas a já referida investigação de Lucia Serrano Pereira, mas também a contigüidade entre, de um lado, o que se tem produzido no cruzamento entre a psicanálise e o texto machadiano e, de outro, aquilo que Augusto Meyer (1952, p.13-20) nomeou, pensando em Dostoiévski, o "homem subterrâneo" em Machado de Assis. A metáfora do subterrâneo é sempre eficiente para acercar-se do inconsciente, porque evoca essa geografia do não-pensado, que a própria escrita pode registrar: "Fique isto confiado a ti somente, papel amigo, a quem digo tudo o que penso e tudo o que não penso", dirá o conselheiro Aires (MA, 16 de junho de 1888).

13 Destaco algumas: Wehrs (1997), Candido (1959, p.23-8), Monteiro (2001), Wisnik (2004), Avelar (2004/2005).

14 Sobre o caráter cênico na situação ficcional machadiana, ver Ferreira (1998, especialmente p.27-39).

15 Recordo aqui as observações de Luís Costa Lima sobre o conselheiro Aires como uma "transmutação tropical" do divertimento da nobreza exilada, de que fala Jean Starobinski com sua idéia das "morais de substituição". Entretanto, o que Starobinski destaca como o caráter estético-consumista da moral substitutiva, Costa Lima chama de caráter ficcional produtivo do afastamento, que aliás não é um afastamento qualquer, ou simples mirada distanciada, mas é o que abre as portas à autoconsciência do processo ficcional. Consulte-se Lima (s. d., especialmente p.69). Não estaríamos tampouco distantes, aqui, do que Abel Barros Baptista (2003) chama "a solicitação do livro" em Machado de Assis.

16 John Gledson (1985, p.143) levou ao extremo o paralelo entre os Tristões e suas mulheres: "The parallels with our story are plain, even if the emotional key is a very different one. Isolde's dilemma between loyalty to her dead knight and her unconscious love of Tristan has the plainest of parallels in Fidélia's loyalty to the memory of her husband and (unconscious?) love of Tristão; certainly, this parallel points to what I am almost inclined to take as an indisputable 'fact' within the fiction of the novel: the two lovers have met 
before, in Lisbon (just as Tristan and Isolde met before in Ireland). It is hardly necessary to conclude that Tristão murdered Eduardo, Fidelia's husband, much as this might add further delightful depths of calculated evil to this 'idyll'. No doubt Machado was aware of the differences between medieval legend in nineteenth-century operatic guise and a realistic novel in diary form, set in the recent past".

17 Gilberto Pinheiro Passos (1996, p.43-6) trabalhou brevemente, em sua ampla pesquisa da malha intertextual do último romance machadiano, a importância de ambas as óperas, de Wagner e Beethoven. Ainda sobre o tema, vale a pena também acompanhar as observações de José Paulo Paes (1985, p.21-2) sobre Beethoven e Machado. Pretendo aqui, contudo, avançar significativamente, tanto quanto possível, a compreensão do Fidelio como referência intertextual de Machado de Assis.

18 A história do libreto do Fidelio torna complicada a referência a um "original". Entretanto, neste ensaio, refiro-me à versão de 1814, quando o argumento de Jean Nicolas Bouilly já havia sido retrabalhado por Joseph Sonnleithner e finalmente por Georg Friedrich Treitschke, e a ópera havia sido reduzida dos três atos iniciais aos dois atos por que hoje a conhecemos. Um roteiro e comentários encontram-se em Robinson (1996).

19 Consulte-se, além da introdução ao já referido livro de Paul Robinson, o capítulo de sua autoria, intitulado "Fidelio and the French Revolution" (Robinson, 1996, p.68-100).

20 Sobre Pascal e Machado de Assis, leia-se Coutinho (1959). Sobre a importância de La Rochefoucauld para a compreensão do "moralismo" machadiano, lembro as reflexões de Alfredo Bosi (1999, passim) e as minhas próprias (Monteiro, 2001, p.449-70).

21 É o que pode sugerir Antonio Candido (1995, p.27) em relação à "técnica" machadiana, que consistiria "em sugerir as coisas mais tremendas da maneira mais cândida (como os ironistas do século XVIII); ou em estabelecer um contraste entre a normalidade social dos fatos e a sua anormalidade essencial; ou em sugerir, sob aparência do contrário, que o ato excepcional é normal, e anormal seria o ato corriqueiro. Aí está o motivo de sua modernidade, apesar do seu arcaísmo de superfície".

22 Sobre a questão dos triângulos amorosos em Machado de Assis, são muito interessantes as observações de José Miguel Wisnik (2004, p.85-6) sobre a "triangulação a um só tempo amorosa, política e musical" no Esaú e Jacó.

$23 \mathrm{Na}$ verdade, nem tão intemporal assim. Se aceitarmos a hipótese de Enylton de Sá Rego (1989), o risível na prosa machadiana poderia ser buscado à sátira menipéia, ou àquilo que o crítico nomeou "tradição luciânica".

24 Sobre a consciência da ação e o domínio viril sobre a parte da fortuna que nos cabe controlar, vale lembrar que, em sua análise da "poesia envenenada de Dom Casmurro", Roberto Schwarz (1997, p.25) dá um toque maquiavélico a Capitu: "Capitu não é Capitu só porque pensa com a própria cabeça. Embora emancipada interiormente da sujeição paternalista, exteriormente ela tem de se haver com essa mesma sujeição, que forma o seu meio. $\mathrm{O}$ encanto da personagem se deve à naturalidade com que se move no ambiente que superou, cujos meandros e mecanismos a menina conhece com discernimento de estadista". Penso ainda no espaço da afirmação feminina que Marta Peixoto $(205$, p.219-4l) vai buscar no mesmo Dom Casmurro, e que porventura valeria a pena descobrir e explorar também no Memorial de Aires.

25 Pelo menos uma vez o desejo de Aires é satisfeito. Significativamente, a realização é onírica (MA, 24 de maio de 1888, ao meio-dia): 
"Esta manhã, como eu pensasse na pessoa que terá sido mordida pela viúva, veio a própria viúva ter comigo, consultar-me se devia curá-la ou não. Achei-a na sala com o seu vestido preto do costume e enfeites brancos, fi-la sentar no canapé, sentei-me na cadeira ao lado e esperei que falasse.

- Conselheiro, disse ela entre graciosa e séria, que acha que faça? Que case ou fique viúva?

- Nem uma cousa nem outra.

- Não zombe, conselheiro.

- Não zombo, minha senhora. Viúva não lhe convém, assim tão verde; casada, sim, mas com quem, a não ser comigo?

- Tinha justamente pensado no senhor.

Peguei-lhe nas mãos, e enfiamos os olhos um no outro, os meus a tal ponto que the rasgaram a testa, a nuca, o dorso do canapé, a parede e foram pousar no rosto do meu criado, única pessoa existente no quarto, onde eu estava na cama. Na rua apregoava a voz de quase todas as manhãs: 'Vai... vassouras! vai espanadores!'

Compreendi que era sonho e achei-lhe graça. Os pregões foram andando, enquanto o meu José pedia desculpa de haver entrado, mas eram nove horas passadas, perto de dez. Fui às minhas abluções, ao meu café, aos meus jornais."

Tive a oportunidade de discutir a passagem em meu ensaio sobre os sonhos no Memorial de Aires (cf. Monteiro, 2001, p.457-8).

26 Refiro-me, é claro, a Quincas Borba.

27 (MA, sem data):

"Há seis ou sete dias que eu não ia ao Flamengo. Agora à tarde lembrou-me lá passar antes de vir para casa. Fui a pé; achei aberta a porta do jardim, entrei e parei logo.

- Lá estão eles, disse comigo.

Ao fundo, à entrada do saguão, dei com os dois velhos sentados, olhando um para o outro. Aguiar estava encostado ao portal direito, com as mãos sobre os joelhos. D. Carmo, à esquerda, tinha os braços cruzados à cinta. Hesitei entre ir adiante ou desandar o caminho; continuei parado alguns segundos até que recuei pé ante pé. Ao transpor a porta para a rua, vi-lhes no rosto e na atitude uma expressão a que não acho nome certo ou claro; digo o que me pareceu. Queriam ser risonhos e mal se podiam consolar. Consolava-os a saudade de si mesmos."

28 Valho-me aqui da tradução de Alfredo Bosi (1999, p.173), em seus "Materiais para uma genealogia do olhar machadiano".

29 O que não nos impede de lembrar a primeira carta que Machado de Assis (1992, v.3, p.1070-1) escreve ao amigo Joaquim Nabuco, depois da morte de Carolina - de quem já se disse que se assemelhava à Carmo do Memorial de Aires: "RJ, 20 nov. 1904. Meu caro Nabuco. Tão longe, em outro meio, chegou-lhe a notícia da minha grande desgraça e V. expressou logo a sua simpatia por um telegrama. A única palavra com que lhe agradeci é a mesma que ora lhe mando, não sabendo outra que possa dizer tudo o que sinto e me acabrunha. Foi-se a melhor parte da minha vida, e aqui estou só no mundo. Note que a solidão não me é enfadonha, antes me é grata, porque é um modo de viver com ela, ouvi-la, assistir aos mil cuidados que essa companheira de 35 anos de casados tinha comigo; mas não há imaginação que não acorde, e a vigília aumenta a falta da pessoa amada. Éramos velhos, e eu contava morrer antes dela, o que seria um grande favor; primeiro, porque não acharia ninguém que melhor me ajudasse a 
morrer; segundo, porque ela deixa alguns parentes que a consolariam das saudades, e eu não tenho nenhum. Os meus são os amigos, e verdadeiramente são os melhores; mas a vida os dispersa, no espaço, nas preocupações do espírito e na própria carreira que a cada um cabe. Aqui me fico, por ora na mesma casa, no mesmo aposento, com os mesmos adornos seus. Tudo me lembra a minha meiga Carolina. Como estou à beira do eterno aposento, não gastarei muito tempo em recordá-la. Irei vê-la, ela me esperará. [...] Aceite este abraço do triste amigo velho MACHADO DE ASSIS".

30 Poderíamos lembrar as belas páginas que Barthes (1977, p.130), em seus fragmentos de um discurso amoroso, reservou ao "fading", muito embora, no seu caso, a angústia de não reencontrar a voz tenha a ver com a perda de um espaço original: a mãe reduzida às sombras, como na Odisséia. "Lorsque l'autre se prend de fading, lorsqu'il se retire, au profit de rien, sinon d'une angoisse qu'il ne peut dire qu'à travers ces pauvres mots: 'je ne me sens pas bien', il semble se mouvoir au loin dans un brouillard; non point mort, mais vivant flou, dans la région des Ombres; Ulysse leur rendait visite, les évoquait (Nekuia); parmi elles était l'ombre de sa mère; j'appelle, j'évoque ainsi l'autre, la Mère, mais ce qui vient n'est qu'une ombre". Tanto pior que, no espaço rarefeito em que se sustenta a voz do conselheiro, não haja sequer angústia aparente, porque lhe falta, a bem da verdade, o que perder. Próximos estaríamos, então, da "falta que pode faltar" lacaniana, que repõe a angústia no terreno em que está ausente e faltante o objeto. Ver, a propósito, Pereira (2004, p.54).

31 "Les morts vont vite", informa Gilberto Pinheiro Passos (1996, cap.2), é o fragmento de um verso da balada Lénore, do poeta alemão Gottfried August Bürger, intensamente traduzida na França, no século XIX, e que Machado talvez tenha conhecido através de Madame de Staël. O "Capítulo dos amores" do livro de Gilberto Passos acrescenta muito à compreensão da malha intertextual com que, de Dante a Beethoven, é tecida a personagem de Machado de Assis.

$32 \mathrm{MA}, 24$ de maio de 1888, ao meio-dia (cf. a nota 25).

33 Trata-se porventura do que José Paulo Paes (1985, p.35-6) chamou "o passado abolido".

Referências bibliográficas

ASSIS, M. de. Bons dias! Ed., introd. e notas de John Gledson. São Paulo, Campinas: Hucitec; Editora da Unicamp, 1990.

1992. v.1.

Obra completa. Org. por Afrânio Coutinho. Rio de Janeiro: Nova Aguilar, A Semana. Ed., introd. e notas de John Gledson. São Paulo: Hucitec, 1996. . Memorial de Aires. São Paulo: Ática, 1999. (Coleção "Bom Livro").

AVELAR, I. Machado de Assis on Popular Music: A Case for Cultural Studies in Nineteenth-Century Latin América. In: ROCHA, J. C. de C. (Ed.) The Author as Plagiarist: The Case of Machado de Assis. Dartmouth, MA: University of Massachusetts, Center for Portuguese Studies and Culture. Portuguese Literary \& Cultural Studies, v.13/14, p.161-75, Fall 2004/Spring 2005.

BANDA, D. Beethoven: Fidelio. Une écoute ressentie. Paris; Montréal: L'Harmattan, 1999. 
BAPTISTA, A. B. Autobibliografias. Solicitação do livro na ficção de Machado de Assis. Campinas: Editora da Unicamp, 2003.

BARTHES, R. Fragments d'un discours amoureux. Paris: Éditions du Seuil, 1977.

BOSI, A. Uma figura machadiana. In: . Machado de Assis: o enigma do olhar. São Paulo: Ática, 1999.

. O teatro político nas crônicas de Machado de Assis. Estudos Avançados, col. "Documentos", n.1, 2004.

CALDWELL, H. The Brazilian Othello of Machado de Assis: a study of Dom Casmurro. Berkeley: University of California Press, 1960.

. O Otelo brasileiro de Machado de Assis: um estudo de Dom Casmurro. Cotia: Ateliê Editorial, 2002.

CANDIDO, A. Música e música, In: O observador literário. São Paulo: Conselho Estadual de Cultura, 1959. p.23-8.

Esquema de Machado de Assis. In: Vários escritos. São Paulo: Duas Cidades, 1995. p.27.

COUTINHO, A. A filosofia de Machado de Assis. In: A filosofia de Machado de Assis e outros ensaios. Rio de Janeiro: Livraria São José, 1959.

FERREIRA, E. F. C. Machado de Assis sob as luzes da ribalta. São Paulo: Cone Sul, 1998.

GLEDSON, J. The Last Betrayal of Machado de Assis: Memorial de Aires. Portuguese Studies, n.1, p.121-50, 1985.

e Terra, 1986.

Machado de Assis: ficção e história. Trad. Sônia Coutinho. Rio de Janeiro: Paz

GUIMARÃES, H. de S. Os leitores de Machado de Assis. O romance machadiano e o público de literatura no século 19. São Paulo: Edusp; Nankin Editorial, 2004.

LA ROCHEFOUCAULD. Réflexions ou Sentences et Maximes Morales. In: Euvres complètes. Ed. L. Martin-Chauffier, Jean Marchand. Paris: Gallimard, 1980. p.403.

LIMA, L. C. O fingidor e o censor. No ancien régime, no Iluminismo e hoje. Rio de Janeiro: Forense Universitária, s. d.

MEYER, A. Da sensualidade na obra de Machado. In: À sombra da estante. São Paulo: José Olympio, 1947. p.37.

O homem subterrâneo. In: . Machado de Assis. Rio de Janeiro: Organização Simões, 1952. p.13-20.

MONTEIRO, P. M. Um sonho machadiano. Estudos Avançados, v.15, n.42, p.44970, 2001. Disponível em: <http://www.scielo.br/scielo.php?script=sci_arttext-\&pidS0103-40142001000200023\&lng-pt\&nrm-iso>.

PAES, J. P. Um aprendiz de morto. In: Gregos \& baianos. São Paulo: Brasiliense, 1985.

PASCAL, B. Pensées (ed. Philippe Sellier). In : LAFOND, J. (Ed.) Moralistes du XVII siècle. Paris: Robert Laffont, 1992. p.335.

PASSOS, G. P. As sugestões do conselheiro. A França em Machado de Assis: Esaú e Jacó e Memorial de Aires. São Paulo: Ática, 1996. 
PEREIRA, L. S. Um narrador incerto entre o estranbo e o familiar: a ficção machadiana na psicanálise. Rio de Janeiro: Companhia de Freud, 2004.

PEIXOTO, M. Dom Casmurro by Machado de Assis. In: KRISTAL, E. (Ed.) The Cambridge Companion to the Latin American Novel. Cambridge: Cambridge University Press, 2005.

REGO, E. de S. O calundu e a panacéia: Machado de Assis, a sátira menipéia e a tradição luciânica. Rio de Janeiro: Forense Universitária, 1989.

ROBINSON, P. Ludwig van Beethoven: Fidelio. Cambridge: Cambridge University Press, 1996.

SCHWARZ, R. Um mestre na periferia do capitalismo: Machado de Assis. São Paulo: Livraria Duas Cidades, 1990.

Duas meninas. São Paulo: Cia. das Letras, 1997.

WEHRS, C. Machado de Assis e a magia da música. Rio de Janeiro: Sette Letras, 1997.

WISNIK, J. M. Machado Maxixe. In: __. Sem receita: ensaios e canções. São Paulo: Publifolha, 2004. p.15-105.

WOOD, M. Master Among the Ruins. The New York Review of Books, July 18, 2002.

RESUMO - O artigo investiga o papel desempenhado pelo Fidelio de Beethoven no $\mathrm{Me}$ morial de Aires de Machado de Assis. Nesse romance extraordinário, o conselheiro Aires evita condenar uma mulher que, entretanto, o seu enganoso diário terminará pondo sob suspeita. Na ópera, Leonora nada esconde, porque abaixo de sua máscara não há nada senão sua lealdade ao marido aprisionado. Machado de Assis, contudo, inicia sua trama num cemitério, onde o marido agora é morto. A importante questão que daí resta é: o que fazer se a fidelidade se refere a um objeto que, seja ele o amado, seja o referente literário, não existe mais?

PALAVRAS-CHAVE: Machado de Assis, Beethoven, Suspeita, Ópera, Literatura e moral, Referencialidade.

ABSTRACT - This article investigates the role played by Beethoven's Fidelio in Machado de Assis' Memorial de Aires. In this extraordinary novel, Counselor Aires avoids condemning a woman who, nevertheless, is put under suspicion by his treacherous diary. In the opera, Leonora hides nothing, because behind her mask there is nothing but loyalty to her imprisoned husband. Machado de Assis, however, begins his novel in a cemetery, where the beloved husband is buried. The main question that is left is: What to do if fidelity refers to an object, be it the beloved or a literary referent, that does not exist any longer?

KErWORDS: Machado de Assis, Beethoven, Suspicion, Opera, Literature and morality, Referentiality.

Pedro Meira Monteiro é professor de Literatura Brasileira na Universidade de Princeton, nos Estados Unidos. É autor de Um moralista nos trópicos: o visconde de Cairu e o duque de La Rochefoucauld (Boitempo, 2004) e A queda do aventureiro: aventura, cordialidade e os novos tempos em Raízes do Brasil (Editora da Unicamp, 1999).

@ - pmeira@Princeton.edu

Recebido em 26.7.2008 e aceito em 20.8.2008. 